Review

\title{
A Systematic Review of HPM Energy Absorbers for Building Applications
}

\author{
Krzysztof Majcher, Michał Musiał (D), Wojciech Pakos (D), Adrian Różański *iD, Maciej Sobótka (D) \\ and Tomasz Trapko (D)
}

check for updates

Citation: Majcher, K.; Musiał, M.; Pakos, W.; Różański, A.; Sobótka, M.; Trapko, T. A Systematic Review of HPM Energy Absorbers for Building Applications. Energies 2021, 14, 6061. https://doi.org/10.3390/en14196061

Academic Editors: George S. Stavrakakis and F. Pacheco Torgal

Received: 1 July 2021

Accepted: 17 September 2021

Published: 23 September 2021

Publisher's Note: MDPI stays neutral with regard to jurisdictional claims in published maps and institutional affiliations.

Copyright: (c) 2021 by the authors. Licensee MDPI, Basel, Switzerland. This article is an open access article distributed under the terms and conditions of the Creative Commons Attribution (CC BY) license (https:// creativecommons.org/licenses/by/ $4.0 /)$.
Faculty of Civil Engineering, Wroclaw University of Science and Technology, pl. Grunwaldzki 11, 50-370 Wrocław, Poland; krzysztof.majcher@pwr.edu.pl (K.M.); michal.musial@pwr.edu.pl (M.M.); wojciech.pakos@pwr.edu.pl (W.P.); maciej.sobotka@pwr.edu.pl (M.S.); tomasz.trapko@pwr.edu.pl (T.T.)

* Correspondence: adrian.rozanski@pwr.edu.pl; Tel.: +48-71-320-40-78

Abstract: A modern weapon, high power microwave (HPM) pulses, can have a profound effect on the quality of functioning of society as the use of this weapon can result in damage to or destruction of electronic equipment and computer and telecommunications systems, both military and civilian. Protection against the energy of HPM pulses can be achieved in two basic ways: by using radiationabsorbent materials (RAM) or artificial electromagnetic (EM) structures. If the object to be protected is a building, protection based on RAM is used. Hence, this literature review focuses on the possibilities of using HPM energy absorbers in building products and structures. Attention is concentrated on four basic types of elements: claddings, concrete and mortar, small-sized elements (bricks, hollow masonry units), and paint coatings. In each of the categories, examples of HPM radiation absorbers having a high potential to be combined with basic construction materials are given on the basis of the literature on the subject.

Keywords: building; materials; protection; HPM; review

\section{Introduction}

Today, digital technologies constitute the basis for the dynamic development of our civilisation. Increasingly more areas of human activity (communications, banking, data acquisition, navigation, etc.) depend on the ubiquitous Internet. The Information Age, in which we currently live, brings with it many threats. One of them is a modern weapon in the form of high power microwave (HPM) pulses. Even though it does not pose a direct threat to human life, as it is a non-lethal weapon [1], it can have a profound effect on the quality of functioning of society due to the fact that many spheres of our life depend on electronic devices. Acts of terrorism or military activities can be directed against the technical infrastructure used for data acquisition, information transmission, and so on. HPM pulses are characterised by frequency in the range of approximately 1 to $100 \mathrm{GHz}$, high power of the emitted pulses (with peak output power on the order of gigawatts), very short duration of the pulses (hundreds of nanoseconds), and a speed of propagation equal to the speed of light [2]. Modern weapons that use HPM pulses consist of a highfrequency transmitter and an omnidirectional or directional antenna. The HPM pulse induces high voltage in power and telecommunication networks and in electrical and electronic equipment. The increased voltage causes a sharp increase in current intensity, generating large amounts of heat and as a result damaging electronic components, electrical circuits, and transmission lines. This means that the use of HPM weapons can pose a great threat to the proper functioning of key infrastructure and, consequently, can contribute to deterioration in the quality of life in a given country. Therefore, many interdisciplinary research teams all over the world have undertaken research on ways of protecting against electromagnetic (EM) pulses. 
Protection against HPM pulses can be achieved in two main ways [3]. One method consists of using radiation-absorbent materials (RAM), while the other method is based on the use of complex artificial electromagnetic structures [4]. Both methods are continually being developed and improved by researchers all over the world. The chosen method to protect against HPM should be fitted to the type of object. Regarding applications in construction, e.g., when the aim is to design a building inside of which electronic equipment (supercomputers, servers, etc.) sensitive to EM radiation will be placed, the method based on RAM seems to be more suitable. RAM is defined as materials that have been specially designed and shaped to absorb EM radiation in a specific frequency range as efficiently as possible. In this sense, concrete with the addition of HPM absorbing materials, shaped into various types of building partitions (walls, ceilings), should definitely be classified as the first type of protection against HPM pulses, i.e., based on RAM. Therefore, this review focuses mainly on this kind of solution for protecting buildings against HPM pulses. The propagation of EM waves in a material depends on both the properties of the material and the wave frequency. When it comes to HPM pulses with frequencies ranging from 1 to $100 \mathrm{GHz}$, the wavelength is greater than the distances between the particles of the material. In a conductive material, the higher the conductivity, the more the wave is damped. Therefore, in well-conducting materials, such as metals, waves of this length penetrate to a limited depth and largely reflect. In a dielectric material, waves undergo changes in speed and length during propagation. In the literature on the subject, the many studies devoted to RAM indicate that researchers have already effectively identified the absorption properties of these materials and demonstrate that research on this subject continues to be developed and carried out by research teams around the world as new solutions, for example, in the form of composites, are still being invented [5-10]. A review of the literature on existing patented solutions shows that, in most cases, EM wave absorbing materials are composites of materials having peculiar properties, such as ferrites-mixed oxides with the generalised formula $\mathrm{MFe}_{2} \mathrm{O}_{4}$ - and ferroelectrics - mainly titanates, metal powders, and carbonic materials (e.g., soot, graphite, and carbon fibers), with lossless or low loss materials [11]. Regarding microwave radiation, effective absorbers include various carbon varieties; semiconductors, such as silicon carbide, titanium dioxide, ferrites and spinels; some transition metals, such as nitrides; and polymers, such as polyaniline [11]. Besides the strong shielding properties of the above mentioned materials, the latter show high potential for being combined with building materials in order to develop new construction solutions, such as cement mortars and concretes with RAM additions, or hybrid structures, e.g., layered walls or composites (e.g., in the form of panels).

According to European law [12] and Polish law [13,14], a building product can be put on the market if its performance meets the basic requirements concerning structural reliability (load-bearing capacity and stability), fire safety, hygiene and health and environment, operational safety, noise protection, energy savings and thermal performance, and the sustainable use of natural resources. However, when developing composite building materials intended for protection against HPM pulses, the main objective should be to obtain the proper level of shielding effectiveness (SE) while maintaining the required mechanical properties (flexural and compressive strength). An important criterion for the development of this type of building materials is the low cost of their manufacture. There are many EM wave absorbing materials (nanopowders of some metals, carbon nanotubes, etc.) on sale that are characterised by a high shielding factor, but the cost of such additions to building materials is so high that their use could be unprofitable. Therefore, when developing an optimal composition of a composite material, taking into account the guidelines contained in [12-14], special attention should be paid to the following basic criteria:

1. meeting the minimum requirements for physical and mechanical properties as well as durability and sustainability (defined in the commonly used design standards),

2. meeting the minimum, pre-assumed requirements for shielding effectiveness (with regard to the individual needs of a particular project),

3. achievement of a low manufacturing cost. 
This article is a sequel to a previous paper by the authors [15], which presented a review of materials that absorb electromagnetic radiation and shield against it. [15] focused mainly on EM radiation-absorbing additions that could potentially be used to modify common building materials such as concrete, resins, or rubber. In particular, the following groups of materials were considered: carbon-based materials [16-20], nickel powder [5-8], iron powder [21,22], ferrites [23,24], magnetites [25-27], polymers and hybrid composite structures [28-30]. By comparison, this paper focuses on the actual use as documented in the literature of EM radiation absorbers in the manufacture of building products, especially constructional ones. Thus, the aim of the paper is to systematise the available knowledge on methods of protecting buildings against HPM pulses. For this purpose, a total of 74 works (64 scientific papers and 10 patents) from widely recognised databases such as Web of Science, Scopus, Google Scholar, and others have been reviewed. The paper addresses an overview of the available methods of protection against HPM that can be used in civil engineering practice. This is mainly, but not limited to, military applications, e.g., bunkers, command centers. However, the reviewed solutions can also be applied to critical civil infrastructure, such as server rooms, headquarters of banks, or other institutions. This has emerged as a more and more important issue in the context of the development of Industry 4.0 and, in particular, Banking 4.0, which are driven by digital integration and automation [31]. Consequently, as key non-military institutions increasingly rely on technology, ensuring their sustained digital security by providing protection against HPM threats is gaining significance.

The survey conducted shows that RAM methods of protection against HPM can be split into several basic groups. The first of them involves the use of specially designed claddings, which are relatively simple and effective methods of protection against EM radiation. This issue is addressed in Section 2. Another primary means of protection consists of the use of appropriately modified construction materials. This group includes concrete and mortar as well as small-sized elements such as bricks or hollow masonry units filled with EM energy absorbing additives (Sections 3 and 4). Finishing materials, in particular special paint coatings, constitute a separate group of methods described in Section 5. Finally, Section 6 contains a recapitulation and frames the concept of a method of manufacturing EM absorbers for buildings.

\section{Claddings}

The ability of metals to conduct electric current and heat is the main basis for their use as shields, providing protection against the action of electromagnetic waves. The simplest and at the same time most effective way of protecting buildings or their components against high-frequency electromagnetic radiation consists of screening them with metal shields in the form of, e.g., claddings [32].

Thick shields, best made of ferromagnetic materials, are used to achieve high shielding effectiveness against magnetic fields. Higher shielding effectiveness is also achieved by using two or more metal layers insulated with a dielectric material. This gives a better field damping effect than the use of a single metal layer of the same thickness. Copper, Mumetal, iron, aluminium, steel, and other materials characterised by a high electric field reflection coefficient and a high magnetic field absorption coefficient can be used together in the form of a hybrid solution [33].

An example of a chamber protected against radiation penetration or escape is shown in Figure 1 (adapted from [33]). According to [30], the condition regarding the dimensions of a shielding structure is as follows: $L \geq 5 \sqrt{H^{2}+W^{2}}$ (denotations as in Figure 1). 


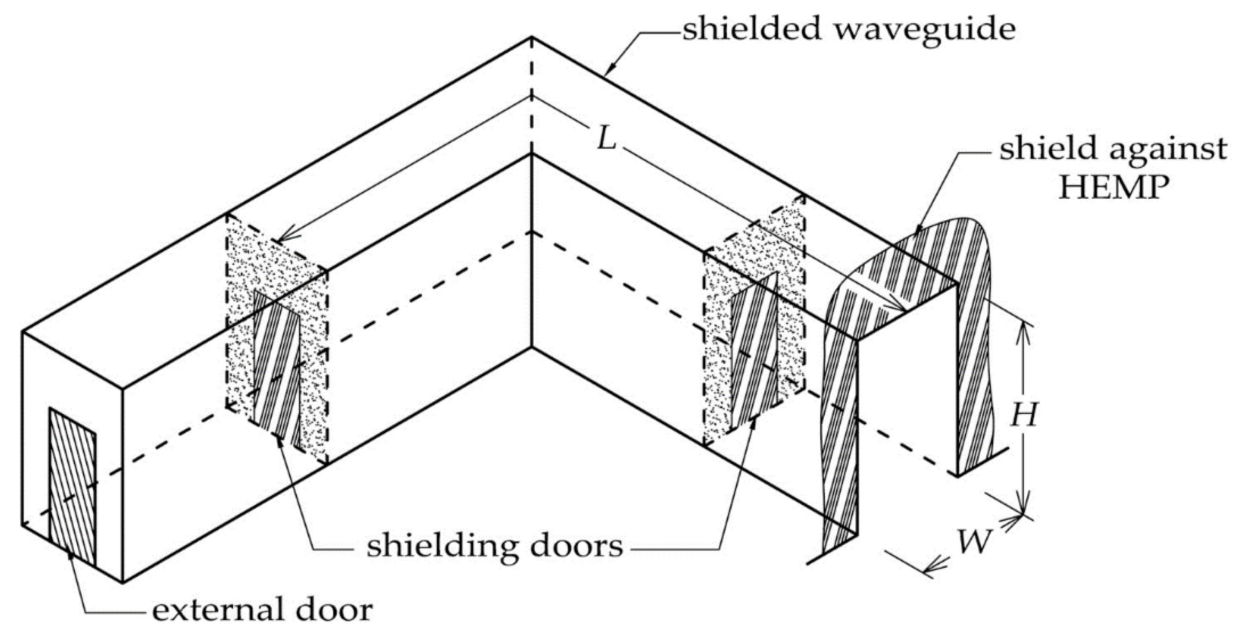

Figure 1. Exemplary structure shielding against high-altitude electromagnetic pulses (HEMP) (after [33]).

Metal nets can be used for shielding purposes, as described in patent [34], which also shows how to join individual wire mesh panels.

Paper [35] proposes a method for making gypsum plasterboards that absorb electromagnetic waves in bands S and C. Honeycomb plasterboard (see Figure 2, adapted from [35]) was coated with carbon black (CB) particles and filled with gypsum. When the plasterboard shielding effectiveness (SE) was tested, the effect of the CB content and the geometric parameters of the carboard core was examined. The test results indicate that the effectiveness of wave absorption by honeycomb plasterboards could be improved by increasing the $\mathrm{CB}$ content and the height of the honeycomb, which resulted in enhanced dielectric capacity and multiple reflections between the honeycomb walls. Furthermore, by shortening the length of the side of a single cell, better absorptive properties could be obtained as the electrical conductivity of the composite increased. For honeycomb cell side length and height amounting to $6 \mathrm{~mm}$ and $9 \mathrm{~mm}$ respectively and a carbon content of $0.6 \%$ wt., a reflection coefficient of $10 \mathrm{~dB}$ (90\% electromagnetic wave absorption) in the frequency range of $2.5-8 \mathrm{GHz}$ was obtained. The tests were carried out according to the Chinese standard GJB 2038a-2011.
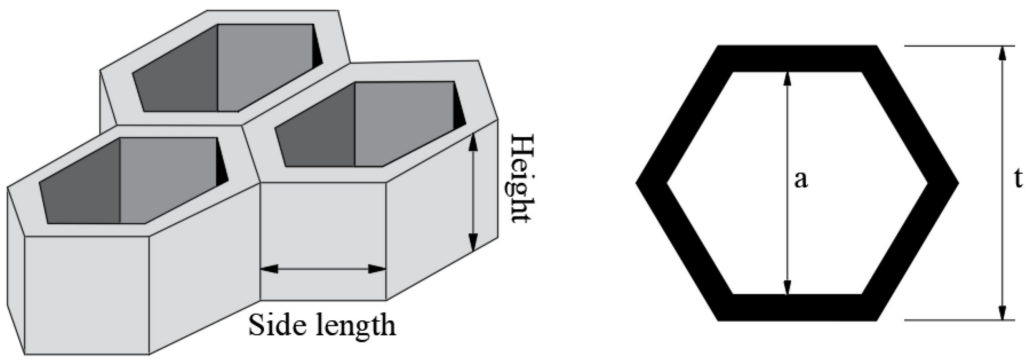

Figure 2. Honeycomb structure and unit cell (after [35]).

Paper [36] describes a method of manufacturing mineral wool boards that absorb microwave radiation. Similarly to paper [35] cited above, carbon black was used as the absorber. The product was endowed with a layered structure. The electromagnetic characteristic of the mineral wool boards was tested in the frequency range of $2-18 \mathrm{GHz}$ by means of scanning and transmission electron microscopy and a vector analyser. In the case of a single-layer board containing 3\% CB, the shielding effectiveness amounted to $10 \mathrm{~dB}$ in the frequency ranges of $2-3 \mathrm{GHz}$ and $7-18 \mathrm{GHz}$. The shielding effectiveness of a double layer mineral wool board exceeded $10 \mathrm{~dB}$ in the whole frequency range $(2-18 \mathrm{GHz})$. The results show that mineral wool boards containing a carbon addition had good absorptive properties and could be used to protect buildings against electromagnetic 
pulses. Furthermore, the adsorptive properties of such boards could be improved if they were fabricated as double-layer.

Carbon fiber paper (CFP) is a thin-layer shielding material characterised by low density and good adhesion and permeability. This type of absorber was used to produce plywood characterised by good shielding effectiveness [37]. In the latter study, the optimal plywood production parameters were found to be pressing pressure of $1.2 \mathrm{MPa}$, temperature of $110 \pm 5^{\circ} \mathrm{C}$ and glue quantity of $380 \mathrm{~g} / \mathrm{m}^{2}$. It was also found that the shielding effectiveness of the composite in the form of plywood with a single CFP layer could be further improved by hot pressing, resulting in better bonding between the conductive carbon fibers. Plywood composites laminated with two layers of CFP were found to have much better microwave screening properties than composites with a single CFP layer. In the case of plywood with two CFP layers, the distance between the absorbing linings had a significant effect on shielding effectiveness. SE increased with increasing distance between the CFP layers. In the frequency range from $30 \mathrm{MHz}$ to $1 \mathrm{GHz}$ an absorption level of over $30 \mathrm{~dB}$ was reached. Thus, CFP is a promising material for the industrial production of wood composites characterised by high shielding effectiveness [37].

A nanocomposite material is proposed in patent [11]. In the form of powder, the material is suitable for use as a component in composites with resins and plastics and as a filler for rubber, whereby an elastic magnetic wave-absorbing material is obtained. According to the patent, it can also be used in the form of pressed boards independently glued to building walls and as an electromagnetic wave absorbing layer placed inside a stiff structural material. Considering the availability of raw materials and the simple manufacturing method, the material can be freely produced.

The subject of patent [34] is an electromagnetic shield which can be used to protect individual rooms or a whole building from electromagnetic radiation. This invention provides strong damping in wide frequency bands. It is also used for protection against nuclear electromagnetic pulses (NEMP), high-altitude electromagnetic pulses (HEMP), and high power microwaves (HPM). According to the invention, the electromagnetic shield consists of current-conducting rods or wires and panels, forming rectangular grids or grid sections, usually made of stainless steel. The advantage of this solution is that the grids can be installed, for example, between the structural layer of the wall and the insulation. In addition, in combination with the building structure, the grid can be used as a reinforcement.

The subject of the patent [38] is an electromagnetic wave absorber with a cementitious matrix, containing 1-20 $\mu \mathrm{m}$ long carbon nanotubes ( $2-10 \% \mathrm{wt}$.). According to the patent specification, the absorber shows excellent absorptive properties and is noncombustible and resistant to high-power radiation. In the frequency range of $1-110 \mathrm{GHz}$, the absorber is characterised by a complex relative permittivity $(\varepsilon)$ of 2-10 and a dielectric loss angle $(\tan \delta)$ equal to or greater than 0.35 .

The above range of $\varepsilon$ is determined by the following facts. If the absorber's $\varepsilon$ value were less than two, the absorber would be ineffective as most electromagnetic radiation would penetrate through it. If the value of $\varepsilon$ were higher than 10 , the absorber would also be ineffective as most of the incident electromagnetic waves would be reflected. The absorber's $\tan \delta$ value greater than or equal to 0.35 ensures the effective conversion of the energy of electromagnetic waves into heat. Possible exemplary shapes of the absorber are shown in Figure 3 (adapted from [38]). 


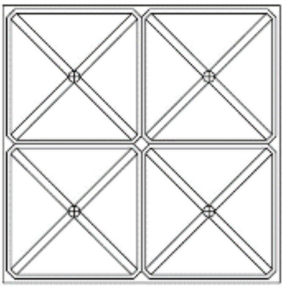

top view

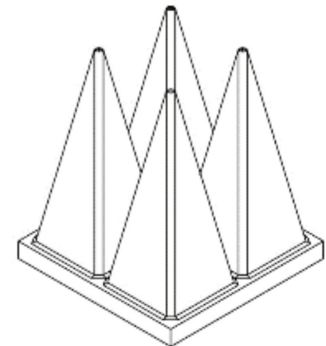

perspective view

(a)

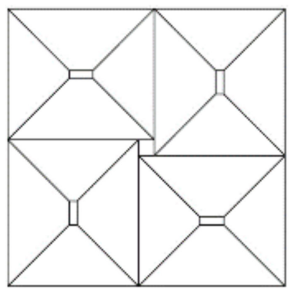

top view

(b)

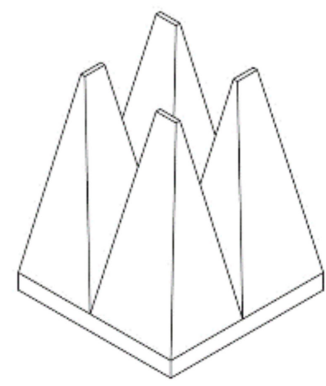

perspective view

Figure 3. Electromagnetic wave absorber with cementitious matrix, containing carbon nanotubes; top view and perspective view: (a) sharp pyramid shape; (b) flat pyramid shape (after [38]).

The patent [39] is for electromagnetic wave absorbing panels for use in building structures, containing an outer layer of protection plates (e.g., silicon matrix plates), an absorber layer, a reflective metal layer, and a bearing layer made of a construction material, e.g., concrete. Generalised and simplified diagrams of the patented absorber are shown in Figure 4 (adapted from [39]). A computer simulation of reflection loss versus frequency for an absorber panel whose $13 \mathrm{~mm}$ thick absorber layer consists of $50 \%$ polycarbonate resin and $50 \%$ of $\mathrm{BaTiO}_{3}+\mathrm{BiFeO}_{3}$ (at the weight ratio of ${ }^{1 / 3}$ ) is shown in Figure 5 (adapted from [39]).
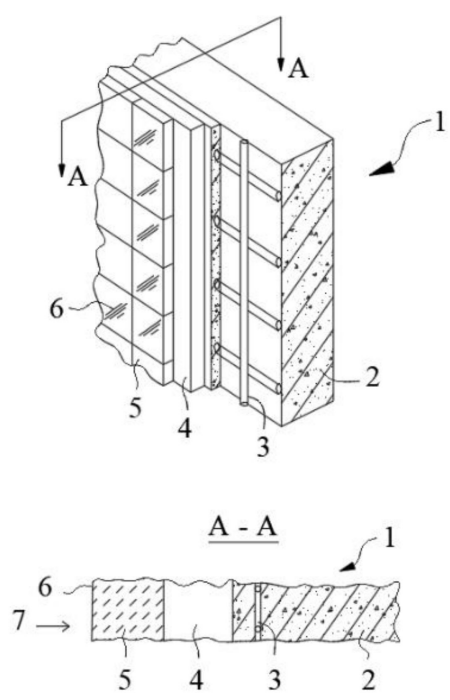

Figure 4. Side view (top) and cross-sectional view (bottom) of the panel absorber. Denotations: 1-panel absorber, 2-bearing layer, 3-reflective layer, 4-absorber layer, 5-outer protective layer, 6 - electromagnetic waves incidence surface, 7-direction of electromagnetic waves incidence (after [39]). 


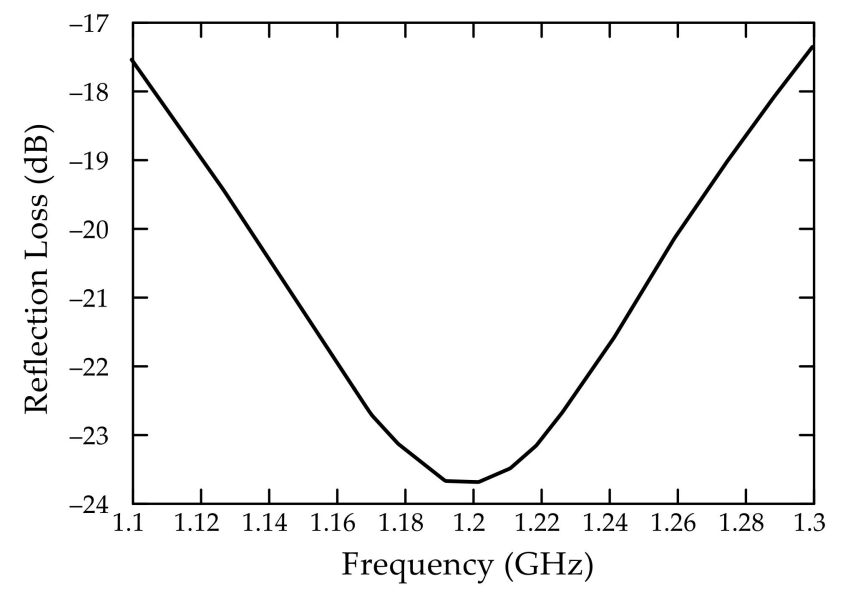

Figure 5. Computer simulation of reflection loss versus frequency for an absorber panel whose $13 \mathrm{~mm}$ thick absorber layer consists of $50 \%$ polycarbonate resin and $50 \% \mathrm{BaTiO}_{3}+\mathrm{BiFeO}_{3}$ (at weight ratio of $1 / 3)$ (after [39]).

In patent [40] the main microwave absorbing component is pure silicon carbide or silicon carbide with titanium dioxide and carbon black additions. The components are bonded together in an elastomer matrix. The damping range can be adjusted by changing the amounts and proportions of the different microwave-absorbing components and by changing the thickness of the material layer. According to the patent, when the microwaveabsorbing material is in the form of a sheet, the advantageous sheet thickness is $1-5 \mathrm{~mm}$ (the most advantageous thickness being in the range of 1.35-2 mm). In the first example provided in [40] the best damping was obtained for a $2.09 \mathrm{~mm}$ thick matrix with a density of $2.04 \mathrm{~g} / \mathrm{cm}^{3}$ at a frequency of $8.6 \mathrm{GHz}$. In the second example the best damping was obtained for a $1.18 \mathrm{~mm}$ thick matrix with a density of $1.93 \mathrm{~g} / \mathrm{cm}^{3}$ at a frequency of $17 \mathrm{GHz}$.

Patent [41] describes an invention in the form of a coating that absorbs the energy of electromagnetic and mechanical waves. Two versions of the coating are proposed. In the first version, the absorbent coating has a substratum in the form of a metal sheet or a polymeric panel on which there is at least one layer of absorber in the form of loose or pressed powder grains, pellets, beads or a gel, overlaid with a polymeric layer. In the second version, the coating contains a substratum on which there is a polymeric (polyurethane) layer, a layer of absorber with a grain size of 2-3 $\mathrm{mm}$ and a $44 \mathrm{wt} . \%$ content of a ferromagnetic substance (FF), and a top layer (polyurea elastomer). The advantage of the coatings is the ease of their installation in all kinds of building structures and also the achievable reduction in EM radiation, amounting to $28-58.2 \mathrm{~dB}$ in the frequency range of $1-10 \mathrm{GHz}$.

The materials discussed above are presented with brief descriptions in Table 1.

Table 1. Summary of the products described in Section 2.

\begin{tabular}{|c|c|c|c|}
\hline Ref. No. & Year & Product & Description \\
\hline [35] & 2016 & $\begin{array}{l}\text { Honeycomb structured } \\
\text { plasterboards }\end{array}$ & $\begin{array}{l}6 \mathrm{~mm} \text { and } 9 \mathrm{~mm} \text { thick boards containing carbon }(0.6 \% \mathrm{wt} .) \text { absorb EM } \\
\text { waves in } \mathrm{S} \text { and C bands. The reflection coefficient of } 10 \mathrm{~dB}(90 \% \\
\text { electromagnetic wave absorption) is obtained in the frequency range of } \\
2.5-8 \mathrm{GHz} \text {. }\end{array}$ \\
\hline [36] & 2016 & $\begin{array}{l}\text { Mineral wool boards with } \\
\text { carbon black }\end{array}$ & $\begin{array}{l}\mathrm{SE} \text { amounts to } 10 \mathrm{~dB} \text { in the frequency ranges of } 2-3 \mathrm{GHz} \text { and } 7-18 \mathrm{GHz} \text { for } \\
\text { a single-layer board containing } 3 \% \mathrm{CB} \text {. The } \mathrm{SE} \text { of a double layer mineral } \\
\text { wool board exceeds } 10 \mathrm{~dB} \text { in the frequency range of } 2-18 \mathrm{GHz} \text {. }\end{array}$ \\
\hline [37] & 2014 & $\begin{array}{l}\text { Plywood composite laminated } \\
\text { with carbon fiber paper }\end{array}$ & $\begin{array}{l}\text { The absorption level reaches more than } 30 \mathrm{~dB} \text { in the frequency range } \\
30 \mathrm{MHz}-1 \mathrm{GHz} \text {. Optimal plywood production parameters are pressing } \\
\text { pressure of } 1.2 \mathrm{MPa} \text {, temperature of } 110 \pm 5^{\circ} \mathrm{C} \text {, and a double amount of } \\
\text { glue, i.e., } 380 \mathrm{~g} / \mathrm{m}^{2} \text {. }\end{array}$ \\
\hline
\end{tabular}


Table 1. Cont.

\begin{tabular}{|c|c|c|c|}
\hline Ref. No. & Year & Product & Description \\
\hline [38] & 2014 & $\begin{array}{l}\text { EM wave absorber with a } \\
\text { cementitious matrix }\end{array}$ & $\begin{array}{l}\text { The absorber contains } 1-20 \mu \mathrm{m} \text { long carbon nanotubes }(2-10 \% \text { wt.). It is } \\
\text { characterised by a complex relative permittivity }(\varepsilon) \text { of } 2-10 \text { and a dielectric } \\
\text { loss angle }(\tan \delta) \text { equal to or greater than } 0.35 \text { in the frequency range of } \\
1-110 \mathrm{GHz} \text {. }\end{array}$ \\
\hline [39] & 1998 & EM wave absorbing panels & $\begin{array}{l}\text { The } 13 \mathrm{~mm} \text { thick absorber layer consists of } 50 \% \text { polycarbonate resin and } \\
50 \% \mathrm{BaTiO}_{3}+\mathrm{BiFeO}_{3} \text { (at weight ratio of } 1 / 3 \text { ). Reflection loss from }-18.5 \text { to } \\
-24 \mathrm{~dB} \text { is obtained in the frequency range of } 1.1-1.3 \mathrm{GHz} \text {. }\end{array}$ \\
\hline [40] & 1995 & $\begin{array}{l}\text { Elastomer matrix composite } \\
\text { with } \mathrm{TiO}_{2} \text { and } \mathrm{CB} \text { additions }\end{array}$ & $\begin{array}{l}\text { The main microwave absorbing component is pure silicon carbide or } \\
\text { silicon carbide with titanium dioxide and carbon black additions. The best } \\
\text { damping is obtained for a } 2.09 \mathrm{~mm} \text { thick layer (density of } 2.04 \mathrm{~g} / \mathrm{cm}^{3} \text { ) at } \\
\text { the frequency of } 8.6 \mathrm{GHz} \text { and for a } 1.18 \mathrm{~mm} \text { (density of } 1.93 \mathrm{~g} / \mathrm{cm}^{3} \text { ) at the } \\
\text { frequency of } 17 \mathrm{GHz} \text {. }\end{array}$ \\
\hline [41] & 2014 & $\begin{array}{l}\text { Coating absorbing EM and } \\
\text { mechanical waves }\end{array}$ & $\begin{array}{l}\text { The product is characterised by the ease of installation in all types of } \\
\text { building structures. Reduction of EM radiation of } 28-58.2 \mathrm{~dB} \text { in the } \\
\text { frequency range of } 1-10 \mathrm{GHz} \text { is achieved. }\end{array}$ \\
\hline
\end{tabular}

\section{Concrete and Mortar}

Suitably modified concrete can be used to protect buildings and rooms against the action of high-frequency electromagnetic radiation. The main purpose of such modifications is to endow concrete with electrical conductivity [42]. Conductive concrete is synthesised by adding a certain amount of a conductive substance, such as steel, graphite, iron slag, nickel, copper [43], carbon nanotubes or ferrites, usually in the form of powders or fibers, which must be properly dispersed within the concrete volume.

Because of the skin effect, the size of the grains / fibers should be as small as possible. To effectively utilise the conductive filler added to the concrete, the size of a single element (the diameter of a particle or fiber) should be equal to $1 \mu \mathrm{m}$ or less. However, thin fibers are not widely available, and it is more difficult to disperse such fillers in comparison with larger-diameter fibers. The difficulties involving the proper dispersion of fibers in cement-based materials and selected methods of dispersing them are described in [44].

To avoid the above problems with filler dispersion, larger (polymeric) fibers or particles coated with a metal are also used, but the drawback of this solution is that the interior of each fiber or particle does not contribute to protection against radiation. Consequently, a higher filler content (volume) must be used $[45,46]$.

Because cement is slightly conductive, it constitutes a better base for producing shielding materials than the commonly used polymers. When a cementitious matrix is used in the shielding composite, this results in better electrical connection between the filler fibers/particles, which are not always in contact. Thus, the shielding effectiveness of cementitious matrix composites is higher than that of composites with a polymeric matrix, which, unlike a cementitious matrix, is a good insulator. In addition, cement is cheaper than polymers and is commonly used in construction; therefore, this material with suitable filler additions can be successfully used to protect buildings or their parts (rooms) against electromagnetic radiation $[45,46]$.

In addition to improving the absorption properties of electromagnetic waves [47], the introduction of fibrous additions, e.g., carbon fibers, into cementitious composites can contribute to an improvement in such properties as compressive strength, flexural strength, and fatigue strength [48].

Paper [49] presents a review of cementitious matrix composites with fillers in the form of short carbon fibers. The composites are characterised by good strength properties, small drying shrinkage, good thermal properties (low thermal conductivity), high electrical conductivity, and high resistance to corrosion. Furthermore, they facilitate cathodic protection of reinforcement steel in concrete. 
The high shielding effectiveness of $40 \mathrm{~dB}$ at the frequency of $1 \mathrm{GHz}$ in the case of a cementitious matrix composite containing $1.5 \%$ (by volume) carbon fibers $0.1 \mu \mathrm{m}$ in diameter is documented in [45]. It was also found that carbon fibers $15 \mu \mathrm{m}$ in diameter are much more dispersible than carbon fibers $0.1 \mu \mathrm{m}$ in diameter, but are less effective in reflecting radio waves (electromagnetic interference (EMI) shielding).

The effectiveness of electromagnetic shielding and absorptive properties of a cementitious composite reinforced with steel fibers, carbon fibers, and synthetic vinyl polymers (PVA) were tested in [50]. The test results show that as the volume fraction of the fibers increased, so did the shielding effectiveness. Moreover, when the volume fractions were changed, the frequency ranges in which the electromagnetic waves were absorbed tended to change. At a steel fiber content of $3 \%$ by volume, SE exceeded $50 \mathrm{~dB}$ for frequencies above $1.8 \mathrm{GHz}$. In the range of $8-18 \mathrm{GHz}$, steel fibers, carbon fibers and PVA fibers could improve the absorptive properties of concrete. Concrete containing $0.5 \%$ carbon fibers attained the best absorptive properties: the minimum reflection coefficient amounted to approximately $7 \mathrm{~dB}$. The optimal steel fiber content amounted to $2 \%$. The reflectivity of concrete reinforced with PVA fibers changed with frequency and the minimum SE value was less than $10 \mathrm{~dB}$ (see Figure 6, adapted from [50]). The results show that fiber-reinforced concrete can be used to protect buildings against EMI due to the enhanced absorption and reflection of electromagnetic waves.

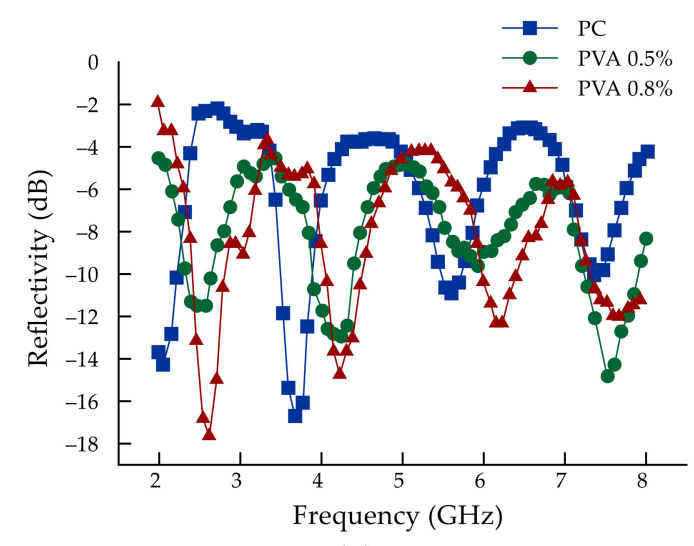

(a)

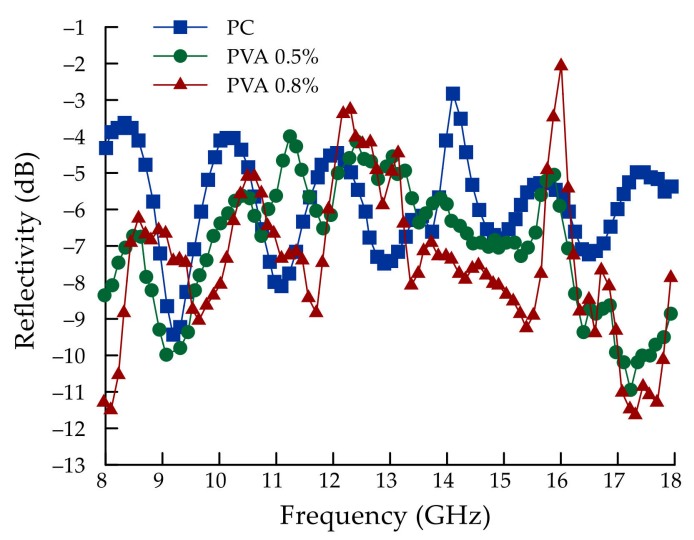

(b)

Figure 6. Reflectivity curve for concrete reinforced with PVA fibers: (a) reflectivity of the S and C wavebands, and (b) reflectivity of the $\mathrm{X}$ and KU wavebands (after [50]).

In [51] it was shown that the absorption capacity of electromagnetic waves of aerated concrete moulded into truncated pyramids improved after adding carbon fibers. The authors found that the absorptive properties of the concrete also strongly depended on the height of the pyramids. The reflection coefficient increased when the height of the pyramids increased from 45 to $80 \mathrm{~mm}$. In the frequency range of $2-18 \mathrm{GHz}$ an absorber in the shape of an $80 \mathrm{~mm}$ high pyramid was characterised by a reflection coefficient of -21 to $-30 \mathrm{~dB}$, while the reflection coefficient of an absorber in the shape of a $45 \mathrm{~mm}$ high pyramid was in a range of -18 to $-27 \mathrm{~dB}$.

Being characterised by good conductive properties, carbon black, one of the cheapest carbon sources, can be used to produce electromagnetic wave absorbers [22]. Carbon black can improve the electric permittivity of an absorber and reduce its thickness and weight. CB can be used jointly with glass fibers. Because of their low electric permittivity, glass fibers improve impedance matching and thereby absorptive properties. They also improve the properties of a cementitious composite, i.e., its bending strength and permeability, and reduce the risk that shrinkage cracks will appear [52]. The effect of the glass fiber content (1-9\% wt.) on the absorptive properties of cement filled with carbon black (5\% wt.) and glass fibers in the frequency range of $2-18 \mathrm{GHz}$ was determined in [53]. It was shown that as the frequency increased, so do the differences between the absorptive properties of the 
materials. The highest minimum reflection loss, i.e., $-11.2 \mathrm{~dB}$ at $18 \mathrm{GHz}$, was registered for the composite with the highest glass fiber content, i.e., $9 \%$ wt., and a thickness of $10 \mathrm{~mm}$.

The shielding effectiveness of concrete samples containing graphite powder in various proportions was compared in [54]. A $20 \mathrm{~cm}$ thick concrete element containing 12\% wt. of graphite powder was found to increase shielding effectiveness (SE) by $2.4 \mathrm{~dB}$ at $360 \mathrm{MHz}$ (see Figure 7, adapted from [54]). It was noted that reflection was the dominant mechanism acting on the shielding effectiveness of concrete with a graphite powder addition.

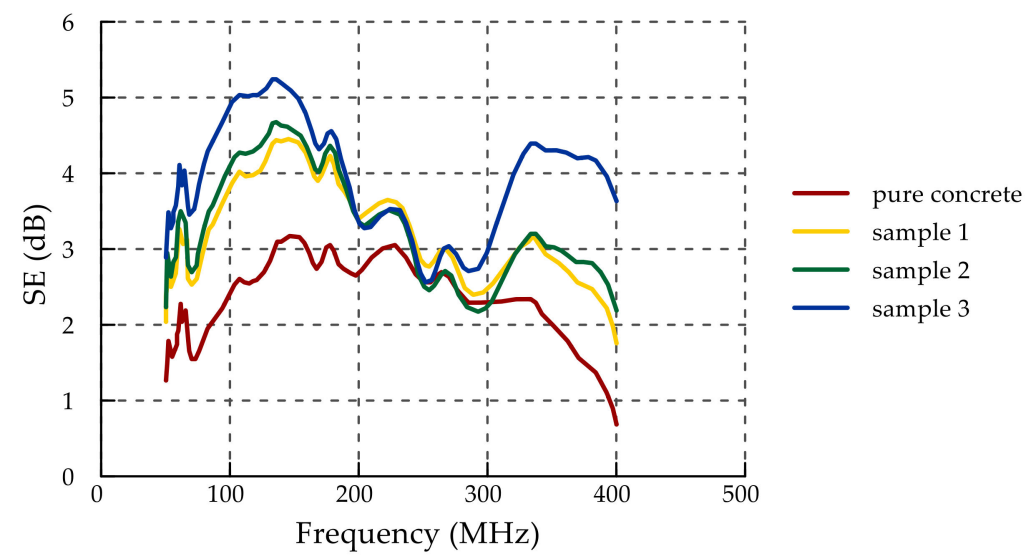

Figure 7. Shielding effectiveness versus wave frequency for the elements tested (after [54]).

The possibility of increasing the electromagnetic shielding of cement-based composite materials with additions derived from agricultural production waste was studied in [55]. Peanut and hazelnut shells were subjected to pyrolysis at the temperature of $850{ }^{\circ} \mathrm{C}$ under an inert atmosphere, ground to a particle size below a micron and added to cement paste. The dispersion of the carbon powder in water was assessed visually, whereas its dispersion in the cement paste was assessed by means of a scanning electron microscope (SEM). The carbon powder was found to be excellently dispersible in the cement paste. A quantitative assessment of the effectiveness of radiation attenuation showed a significant improvement due to the addition of pyrolysed nutshells to cement-based composites. At the $0.5 \%$ content of this addition, the shielding effectiveness increased maximally by $353 \%, 223 \%, 126 \%$ and $83 \%$ at $0.9 \mathrm{GHz}, 1.56 \mathrm{GHz}, 2.46 \mathrm{GHz}$ and $10 \mathrm{GHz}$ respectively. The experimental and simulation results show that the considered addition was more dispersible than carbon nanotubes (CNT) or graphene and highly effectively enhanced the EMI shielding properties of cement-based composites.

As part of the study [56], four types of building materials were tested to ensure adequate shielding effectiveness. The tests were carried out in a specially designed installation in a fully anechoic room. Two by two meter walls, each weighing up to $3.5 \mathrm{t}$, were tested. As expected, unmodified gypsum boards and concrete slabs were found to be ineffective in protecting against electromagnetic radiation. In the case of the gypsum boards, when the usual polyethylene sheeting was replaced with aluminium sheeting, the shielding effectiveness considerably increased. In the case of concrete slabs, it was shown that a steel fiber reinforcement addition extended the range of frequencies (to higher frequencies) for which protection was more effective.

The high shielding effectiveness (amounting to $70 \mathrm{~dB}$ at the frequency of $1.5 \mathrm{GHz}$ ) of a cement-based composite was documented in study [57]. The composite tested was a cement paste containing $0.72 \%$ (by volume) of $8 \mu \mathrm{m}$ in diameter and $6 \mathrm{~mm}$ long stainless steel fibers and admixtures facilitating the dispersion of the fibers in the cement paste. The electrical resistivity amounted to $16 \Omega \mathrm{cm}$. In this case, shielding resulted from the reflection of waves, as indicated by the low absorption of $1.7 \mathrm{~dB}$ (at the frequency of $1.5 \mathrm{GHz}$ ). It should be noted that, already at a steel fiber content of $0.36 \%$ (by volume), shielding effectiveness amounted to $58 \mathrm{~dB}$ at a frequency of $1.5 \mathrm{GHz}$ and resistivity was $57 \Omega \mathrm{cm}$. At 
the radiation frequency of $1.0 \mathrm{GHz}$ the shielding effectiveness was lower, reaching $60 \mathrm{~dB}$ at the fiber content of $0.72 \%$.

The shielding effectiveness of a cement-based composite with a steel fibers and graphite powder addition was tested in study [58]. Special attention was paid to SE variation (mainly due to drying) during the curing of the samples. The results are of interest for the manufacture of shields for buildings, as they showed SE decreasing during the drying of the samples. Figure 8 (adapted from [58]) shows that the damping caused by the water contained in the samples was particularly significant in the range of lower frequencies (1-4 GHz). In the case of samples containing $20 \%$ graphite and those containing $10 \%$ graphite and $10 \%$ steel fibers, the effect of drying for 6 months on the shielding capacity for waves in the range of $4-10 \mathrm{GHz}$ was negligible.
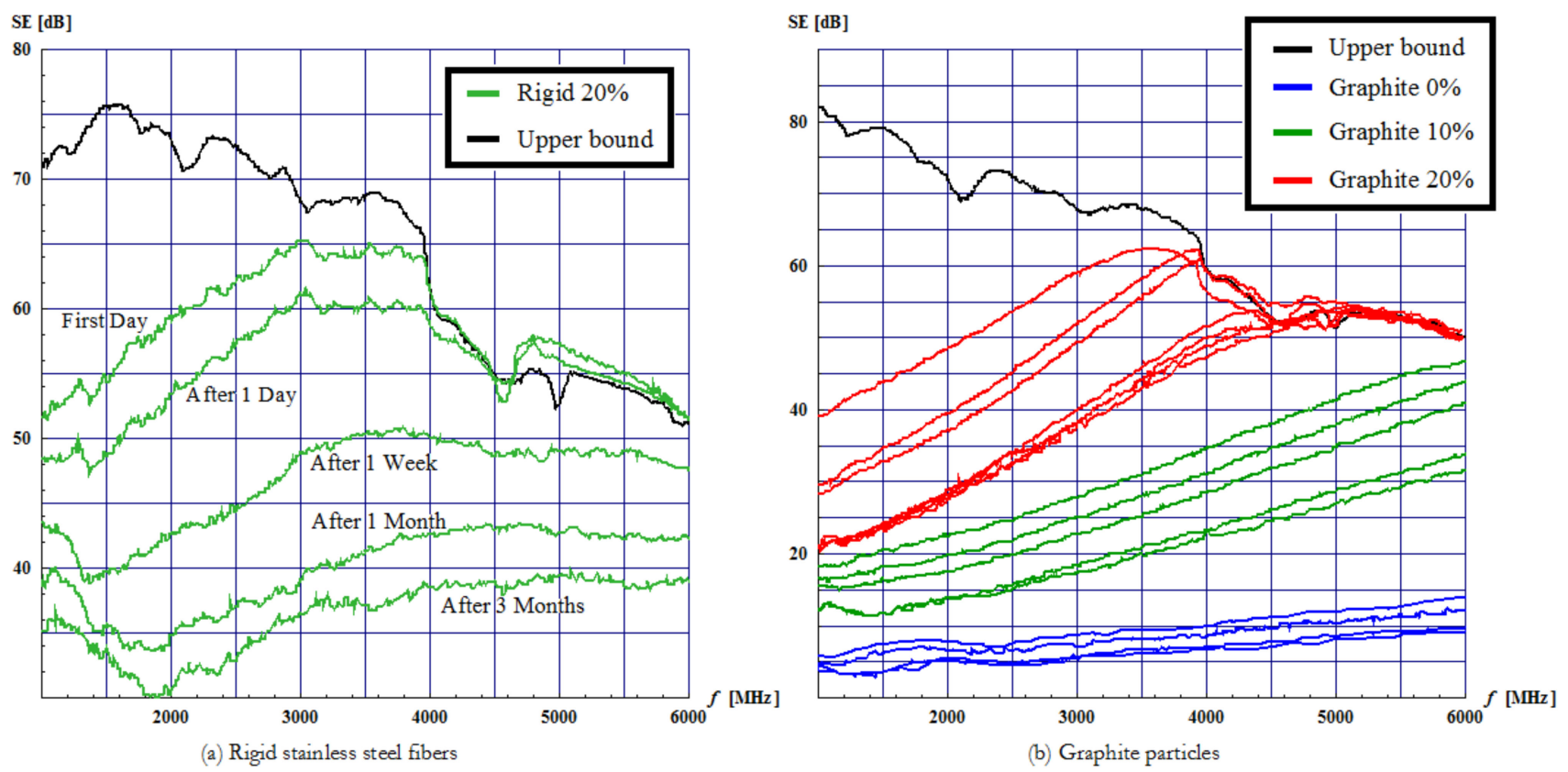

Figure 8. Shielding effectiveness versus wave frequency for tested elements: (a) material with steel fibers addition, (b) material with graphite addition (after [58]).

The study [59] dealt with the electromagnetic characteristic and shielding effectiveness of cementitious matrix composites containing multi-walled nanotubes (MWNT) in the frequency range of $0.1-8 \mathrm{GHz}$. In order to achieve proper dispersion of multi-walled nanotubes in the composite, MWNTs were first mixed with a surface-active agent and then subjected to sonication. The quality of the MWNT dispersion in water was assessed by analysing the VIS absorption spectrum, the near-UV spectrum, and the near-IR spectrum. The quality of MWNT dispersion in the cementitious matrix was assessed by examining the fracture surface under a scanning electron microscope (SEM). Shielding effectiveness was measured using a network analyser with a coaxial transmission line. The most effective shields in a wide frequency range were obtained by adding 1.5\% of MWNTs in proportion to the cement content. The produced materials exhibited better EM waves screening in band $\mathrm{X}$, but a degradation of shielding effectiveness was observed due to air voids in the materials. SEM examinations showed that most of the MWNTs were separated and deposited in the cement hydration product. Therefore, one can conclude that composite materials with a MWNT addition can be used as shields against electromagnetic pulses.

The shielding effectiveness of two and three-layer cementitious matrix panels containing MWNT (10-20 nm in diameter and 10-30 $\mu \mathrm{m}$ long), $\mathrm{Fe}_{2} \mathrm{O}_{3}$ nanoparticles $(20 \mathrm{~nm})$ and $\mathrm{NiO}$ nanoparticles $(60 \mathrm{~nm})$ for use in military and civil installations was evaluated in study [60]. In addition to the components mentioned above, a polycarbonate superplasticiser and a dispersant were used to produce the panels. In the case of the three-layer panels, 
ceramic granulate was introduced into its top layer. The composition of the composites is shown in Table 2. The mechanical and absorptive properties of the panels were tested in the frequency range of 2-18 GHz. The two-layer panels showed better mechanical properties. Their compressive strength amounted to $61.2 \mathrm{MPa}$, i.e., $12 \mathrm{MPa}$ higher than that of the three-layer panels, but the latter panels had better absorptive properties (see Figure 9, adapted from [60]). As the authors explain, this was mainly due to the presence of ceramic granulate, characterised by low values of electromagnetic parameters and high porosity, in the top layer. These properties of the granulate contributed to better impedance matching.

Table 2. Composition (in grams) of sandwich composite panels (after [60]).

\begin{tabular}{|c|c|c|c|c|c|c|c|c|c|c|}
\hline $\begin{array}{l}\text { Number } \\
\text { of Layers }\end{array}$ & Layer & Cement & $\mathrm{Fe}_{2} \mathrm{O}_{3}$ & $\mathrm{NiO}$ & MWNT & Water & Superplasticiser & $\begin{array}{c}\text { Dispersing } \\
\text { Agent }\end{array}$ & $\begin{array}{l}\text { Ceramic } \\
\text { Granulate }\end{array}$ & $\begin{array}{c}\text { Thickness } \\
\text { [mm] }\end{array}$ \\
\hline \multirow{2}{*}{ Two } & top & 945 & - & - & 4.725 & 253 & 7.56 & 3.78 & - & 14 \\
\hline & bottom & 675 & 283 & 94 & - & 256.5 & 5.40 & - & - & 14 \\
\hline \multirow{3}{*}{ Three } & top & 360 & - & - & - & 70 & 2.52 & - & 150 & 6 \\
\hline & middle & 540 & - & - & 2.7 & 140.4 & 4.32 & 2.7 & - & 11 \\
\hline & bottom & 540 & 228 & 75.6 & - & 205.2 & 4.32 & - & - & 11 \\
\hline
\end{tabular}

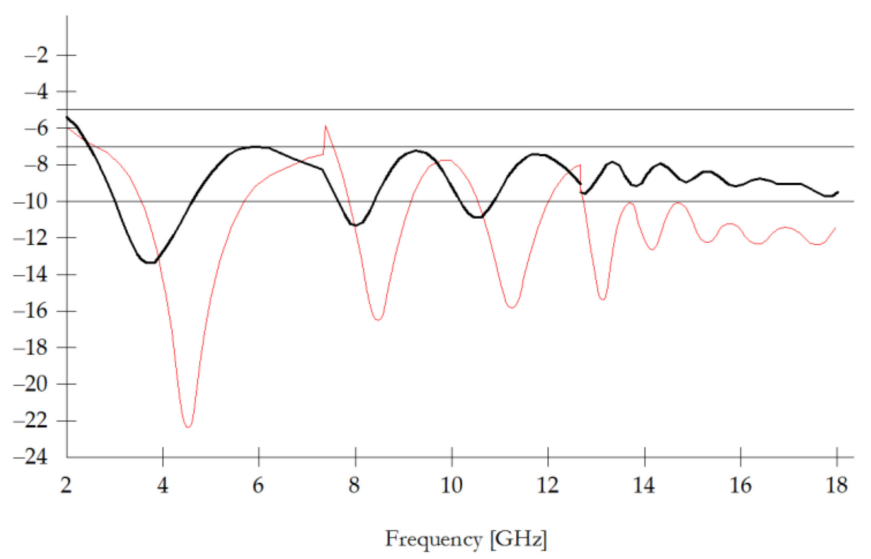

Figure 9. Reflectivity versus frequency for two-layer panels (black) and three-layer panels (red) (after [57]).

In study [61], dealing with the making of layered cementitious matrix composite absorbers, rubber powder, manganese-zinc ferrite, and manganese-zinc ferrite together with carbon fibers were used as porosity-increasing additions in, respectively, the top layer, the middle layer and the bottom layer. Each of the layers was $10 \mathrm{~mm}$ thick. The composition of the particular absorber layers is shown in Table 3. The presence of rubber powder in the top layer was found to improve impedance matching with voids. As a result, most of the incident electromagnetic waves entered the absorber, where they were damped in the middle and bottom layers. The ferrite-containing middle layer was characterised by high magnetic and electric permittivity, damping the energy of electromagnetic waves because of magnetic and dielectric losses. Owing to the presence of conductive carbon fibers in the bottom layer, the losses due to the multiple reflection mechanism increased. The authors demonstrated that the absorber they created was characterised by reflection losses below $-10 \mathrm{~dB}$ in the frequency range of $8-18 \mathrm{GHz}$.

Table 3. Composition of the particular absorber layers (after [61]).

\begin{tabular}{ccccccc}
\hline Layer & Cement & W/C Ratio & $\begin{array}{c}\text { Cement/Sand } \\
\text { Ratio }\end{array}$ & $\begin{array}{c}\text { Superplasticiser } \\
{\left[\% \text { wt. } \text { * }^{*}\right.}\end{array}$ & $\begin{array}{c}\text { Rubber } \\
{[\% \text { wt. }]_{* * *}^{*}}\end{array}$ & $\begin{array}{c}\text { Carbon Fibers } \\
{[\% \text { wt.] }}\end{array}$ \\
\hline top & 1 & 0.3 & $1 / 1.5$ & 0.5 & 10 & - \\
middle & 1 & 0.3 & $1 / 1.5$ & 0.5 & - & - \\
bottom & 1 & 0.3 & $1 / 1.5$ & 0.5 & - & 30 \\
\hline
\end{tabular}


The good properties of a layered resistive coating/absorbing layer/reflecting layer system were demonstrated in study [62]. The absorber layers, each $1.4 \mathrm{~cm}$ thick, were joined together using commercial adhesives. Each of the two layers of adhesive was approximately $0.1 \mathrm{~mm}$ thick. The resistive coating was a carbon coating produced from nitrocellulose lacquer filled with graphite and black carbon, using ethyl acetate as the solvent. Foamed cement reinforced with polypropylene fibers $(0.3 \% \mathrm{wt}$.) constituted the absorbing layer. Hydrogen peroxide ( $5 \%$ wt.) was used as the foaming agent. Calcium stearate ( $2 \%$ wt.) was used as the foam stabiliser. Chloride $(1.5 \%$ wt.) was used as the substance increasing the initial strength. Polyvinyl alcohol ( $2 \% \mathrm{wt}$.) was used as the binder. The metal sheet constituted the reflecting layer. In the frequency range of $2-4 \mathrm{GHz}$ the absorption band of the produced composite was 100\% below $-10 \mathrm{~dB}$ and $95 \%$ below $-14 \mathrm{~dB}$, with the maximum absorption of $-19.6 \mathrm{~dB}$ at $2.45 \mathrm{~Hz}$.

Extruded polystyrene (EPS) has good properties, such as low density, high strength, low water absorbability, and high acid and base resistance, and is widely used in the building industry [63]. As a kind of light aggregate, EPS beads can be easily introduced into mortar or concrete to obtain light mortars or concretes, widely varying in their density. Cement-based composites filled with EPS show good thermal performance, and moreover, can be used to limit the interference of EM waves in rooms. In studies $[63,64]$ the absorptive properties of a cement-based composite filled with EPS were tested and the test results were compared with those obtained for corresponding samples without EPS. It was shown that the addition of EPS could improve the effectiveness of microwave damping. In addition, the effects of the EPS filling ratio, the particle diameter, and the composite thickness on absorption effectiveness were studied. The lowest shielding effectiveness in the frequency range of 8-18 GHz amounted to approximately $15 \mathrm{~dB}$ for a $20 \mathrm{~mm}$ thick sample with a volume fraction of EPS beads $1.0 \mathrm{~mm}$ in diameter amounting to $60 \%$. It was also shown that the damping of electromagnetic waves could be ascribed mainly to multiple reflection and dispersion inside the composite material.

In study [65] the effect of carbon fibers on the resistivity of gypsum-based plaster was examined. Owing to the $2.0 \% \mathrm{wt}$. addition of $3 \mathrm{~mm}$ long carbon fibers to gypsumbased plaster, its resistivity was reduced to $0.02 \%$ of the resistivity of ordinary gypsum plaster (without fibers). The effectiveness of shielding against electromagnetic interference increased monotonically with the fiber content, reaching $22 \mathrm{~dB}$ at $1.5 \mathrm{GHz}$ for a plaster thickness of $4.35 \mathrm{~mm}$ and a fiber content of $2.0 \% \mathrm{wt}$. Furthermore, even at the lower fiber content of $0.3 \%$, shielding effectiveness amounted to $10 \mathrm{~dB}$ at wave frequency of $1.5 \mathrm{GHz}$ and plaster thickness of $3.85 \mathrm{~mm}$. The additional use of chemical agents (sodium citrate, cement, and aluminium sulphate) increased electric resistivity, only slightly affecting shielding effectiveness. At the same time, the added chemical agents improved the mechanical properties of the plaster.

The authors of patent [66] added, among other things, a very soft ferromagnetic material (developed by the authors) to ferrite powder, obtaining a material with novel properties. Depending on the type and amount of particular components used in accordance with the patent instructions, the composite material can be produced in any physical state, e.g., a solid, foamed solid, semi-solid, semi-liquid, gel-like, or liquid state. Material in a semi-solid, semi-liquid, gel-like, or liquid state can be produced with any suitable consistency or viscosity, e.g., in the form of paste or mastic, depending on the desired end use. Another advantage of this material is that its mechanical and electrical properties can be adapted to a large extent individually through the proper preparation of the components of the composite. The proposed composite material exhibits strong electromagnetic energy absorption in the range of radio and microwave frequencies and better magnetic and dielectric loss properties in comparison with its components.

A summary of the individual products discussed in this Section, with their main features, is presented in Table 4. 
Table 4. Summary of the products described in Section 3.

\begin{tabular}{|c|c|c|c|}
\hline Ref. No. & Year & Product & Description \\
\hline [45] & 2001 & $\begin{array}{l}\text { Cementitious matrix composite } \\
\text { with carbon fibers }\end{array}$ & $\begin{array}{l}\text { SE of } 40 \mathrm{~dB} \text { is reached at the frequency of } 1 \mathrm{GHz} \text { for } 1.5 \% \text { vol. of carbon fibers } \\
0.1 \mu \mathrm{m} \text { in diameter. }\end{array}$ \\
\hline [50] & 2012 & $\begin{array}{l}\text { Cementitious composite } \\
\text { reinforced with steel fibers, } \\
\text { carbon fibers, and synthetic vinyl } \\
\text { polymers (PVA) }\end{array}$ & $\begin{array}{l}\text { SE exceeds } 50 \mathrm{~dB} \text { at frequencies above } 1.8 \mathrm{GHz} \text { for steel fiber content of } 3 \% \text { vol. The } \\
\text { minimum reflection coefficient amounts to approximately } 7 \mathrm{~dB} \text { for concrete } \\
\text { containing } 0.5 \% \text { carbon fibers in the frequency range of } 8-18 \mathrm{GHz} \text {. The reflectivity of } \\
\text { concrete reinforced with PVA fibers changes with frequency and the minimum SE } \\
\text { value is less than } 10 \mathrm{~dB} \text {. }\end{array}$ \\
\hline [51] & 2008 & $\begin{array}{l}\text { Aerated concrete moulded into } \\
\text { truncated pyramids with addition } \\
\text { of carbon fibers }\end{array}$ & $\begin{array}{l}\text { In the frequency range of } 2-18 \mathrm{GHz} \text {, the absorber in the shape of an } 80 \mathrm{~mm} \text { high } \\
\text { pyramid is characterised by reflection coeff. of }-21 \text { to }-30 \mathrm{~dB} \text {, while the reflection } \\
\text { coeff. of an absorber in the shape of a } 45 \mathrm{~mm} \text { high pyramid is in the range of }-18 \text { to } \\
-27 \mathrm{~dB} \text {. }\end{array}$ \\
\hline [53] & 2014 & $\begin{array}{l}\text { Cement filled with carbon black } \\
\text { and glass fibers }\end{array}$ & $\begin{array}{l}\text { The minimum reflection loss equals }-11.2 \mathrm{~dB} \text { at } 18 \mathrm{GHz} \text { for glass fiber content of } 9 \% \\
\text { wt. and carbon black content of } 5 \% \text { wt.; the thickness of sample is } 10 \mathrm{~mm} \text {. }\end{array}$ \\
\hline [54] & 2013 & $\begin{array}{l}\text { Concrete samples filled with } \\
\text { graphite powder }\end{array}$ & $\begin{array}{l}\text { The addition of graphite powder ( } 12 \% \text { wt.) increases the } \mathrm{SE} \text { of a } 20 \mathrm{~cm} \text { thick concrete } \\
\text { element by } 2.4 \mathrm{~dB} \text { at } 360 \mathrm{MHz} \text {; reflection is the dominant mechanism that has an } \\
\text { impact on shielding effectiveness. }\end{array}$ \\
\hline [55] & 2015 & $\begin{array}{l}\text { Cement-based composite } \\
\text { materials with additions derived } \\
\text { from agricultural } \\
\text { production waste }\end{array}$ & $\begin{array}{l}\text { For } 0.5 \% \text { content of pyrolysed nutshells, the SE increases by } 353 \%, 223 \%, 126 \% \text { and } \\
83 \% \text { at } 0.9 \mathrm{GHz}, 1.56 \mathrm{GHz}, 2.46 \mathrm{GHz} \text { and } 10 \mathrm{GHz} \text {, respectively. }\end{array}$ \\
\hline [56] & 2007 & Gypsum boards & $\begin{array}{l}\text { Shielding effectiveness increases considerably when the usual polyethylene sheeting } \\
\text { is replaced with aluminium sheeting. }\end{array}$ \\
\hline [56] & 2007 & $\begin{array}{l}\text { Steel fiber reinforced } \\
\text { concrete slabs }\end{array}$ & $\begin{array}{l}\text { The addition of steel fiber extends the range of frequencies (to higher frequencies) } \\
\text { for which protection is more effective. }\end{array}$ \\
\hline [57] & 2004 & $\begin{array}{l}\text { Cement paste with stainless } \\
\text { steel fibers }\end{array}$ & $\begin{array}{l}\text { SE reaches } 70 \mathrm{~dB} \text { at } 1.5 \mathrm{GHz} \text { and } 60 \mathrm{~dB} \text { at } 1.0 \mathrm{GHz} \text { for fiber content of } 0.72 \% \text { vol; fiber } \\
\text { diameter: } 8 \mu \mathrm{m} \text {; fiber length: } 6 \mathrm{~mm} \text {. }\end{array}$ \\
\hline [58] & 2009 & $\begin{array}{l}\text { Cement-based composite with the } \\
\text { addition of steel fibers and/or } \\
\text { graphite powder }\end{array}$ & $\begin{array}{l}\text { SE reaches over } 70 \mathrm{~dB} \text { in the frequency range } 1.0-2.5 \mathrm{GHz} \text { for hybrid sample } \\
\text { containing both additions ( } 10 \% \text { wt each); SE decreases during drying, resulting in a } \\
\text { value of about } 50 \mathrm{~dB} \text { after } 6 \text { months. }\end{array}$ \\
\hline [59] & 2012 & $\begin{array}{l}\text { Cementitious matrix composites } \\
\text { containing multi-walled } \\
\text { nanotubes }\end{array}$ & $\begin{array}{l}\text { Addition of } 1.5 \% \text { wt. results in improved SE across the overall frequency range } \\
(45 \mathrm{MHz} \text { to } 18 \mathrm{GHz} \text { ), in particular, by } 32 \% \text { at } 0.8 \mathrm{MHz} \text {. }\end{array}$ \\
\hline
\end{tabular}

Sandwich cementitious matrix

[60] 2017 panels containing MWNT, $\mathrm{Fe}_{2} \mathrm{O}_{3}$ nanoparticles, and $\mathrm{NiO}$ nanoparticles

Layered cementitious matrix

[61] 2011 composite absorbers with rubber

powder, manganese-zinc ferrite and carbon fibers

Layered absorber made of carbon coating (with graphite and black

[62] 2013 carbon), foamed cement (reinforced with polypropylene fibers) and metal reflecting layer

\begin{tabular}{ccc}
\hline$[63,64]$ & 2007 & $\begin{array}{c}\text { Cement-based composites filled } \\
\text { with EPS beads }\end{array}$ \\
\hline$[65]$ & 1989 & $\begin{array}{c}\text { Gypsum plaster reinforced with } \\
\text { carbon fiber }\end{array}$ \\
\hline
\end{tabular}

[66] $2003 \quad$ Energy absorbing material
Reflectivity reaches $-13 \mathrm{~dB}$ at a frequency of about $4.0 \mathrm{GHz}$ for a two-layer panel and $-22 \mathrm{~dB}$ at about $4.5 \mathrm{GHz}$ for a three-layer panel.

The three-layer absorber is characterised by reflection loss below $-10 \mathrm{~dB}$ in the frequency range of $8-18 \mathrm{GHz}$.

In the frequency range of $2-4 \mathrm{GHz}$ the absorption band of the produced composite was $100 \%$ below $-10 \mathrm{~dB}$ and $95 \%$ below $-14 \mathrm{~dB}$, with a maximum absorption of $-19.6 \mathrm{~dB}$ at $2.45 \mathrm{~Hz}$.

Minimum SE amounts to about $15 \mathrm{~dB}$ in the frequency range of $8-18 \mathrm{GHz} \mathrm{dB}$ for a $20 \mathrm{~mm}$ thick sample with $60 \%$ vol. EPS beads $1.0 \mathrm{~mm}$ in diameter.

SE increases with fiber content, reaching $22 \mathrm{~dB}$ at $1.5 \mathrm{GHz}$ for a plaster thickness of $4.35 \mathrm{~mm}$ and a fiber content of $2.0 \%$ wt. For fiber content of $0.3 \%$ and plaster thickness of $3.85 \mathrm{~mm} \mathrm{SE}$ amounts to $10 \mathrm{~dB}$ at $1.5 \mathrm{GHz}$.

The composite material exhibits strong electromagnetic energy absorption in the range of radio and microwave frequencies and better magnetic and dielectric loss properties compared to its components, among other things, very soft ferromagnetic material (developed by the authors of patent [66]) and ferrite powder. 


\section{Bricks and Hollow Masonry Units-Small-Sized Elements}

The possibility of using a mill scale as an admixture in the manufacture of ceramic bricks with enhanced shielding effectiveness was investigated in study [67]. The admixture, amounting up to $20 \% \mathrm{wt}$., improved the properties of ceramic bricks owing to its melting action and formation of magnesioferrite in the sintered ceramic body fired at a temperature of over $900{ }^{\circ} \mathrm{C}$. Ceramic bricks, in the manufacture of which a $15-20 \%$ wt. addition of mill scale with a particle size of $0.5 \mathrm{~mm}$ was used, exhibited an average shielding effectiveness of up to $4 \mathrm{~dB}$. Sandwich ceramic tiles of the same dimensions, containing a similar amount of scale, exhibited a higher average shielding effectiveness of up to $8 \mathrm{~dB}$ in the same $X$ band frequency range. The reflection effect was almost independent of the addition. The physical and mechanical characteristics (absorption capacity, fire shrinkage, modulus of elasticity and compressive strength) of the sandwich ceramic tiles were within acceptable limits. Furthermore, a leaching test showed that all toxic elements tested were stabilised in the sintered ceramic structure of the ceramic bricks and ceramic tiles. The bricks/tiles tested and the larger elements made up of them are shown in Figure 10 (adapted from [67]).

a)

$15 \%$ or $20 \%$ MS brick $(10 \times 10 \times 3) \mathrm{cm}$
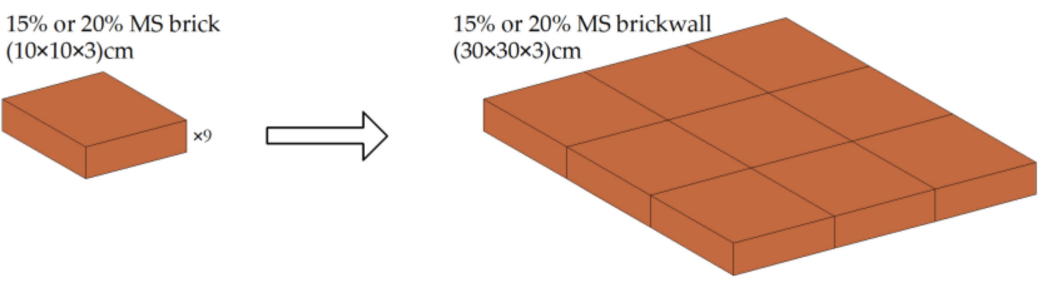

b) $15 \%$ or $20 \%$ MS tile $(10 \times 10 \times 1) \mathrm{cm}$

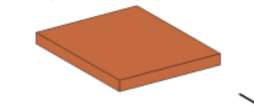

$10 \%$ MS portland cement type A $1 \mathrm{~cm}$ width
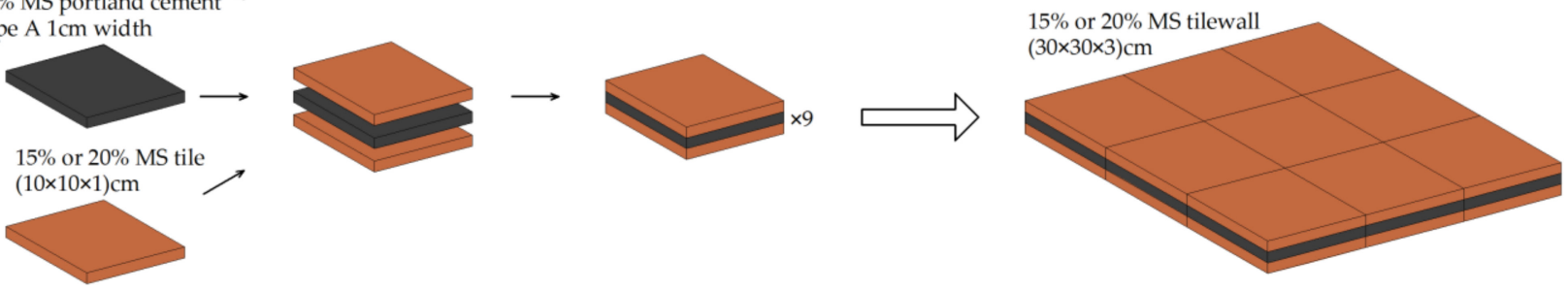

Figure 10. Tested: (a) bricks, (b) tiles, and larger elements made up of them (after [67]).

Ceramic elements containing a metallurgical slag admixture were tested in study [68]. Tests carried out in the $\mathrm{X}$-wave range $(8-12 \mathrm{GHz}$ ) showed a shielding effectiveness of up to $2 \mathrm{~dB}$ or $3 \mathrm{~dB}$, depending on the slag used, at slag content of $10-20 \% \mathrm{wt}$. Similarly to the case of study [67], the physical and mechanical characteristics of the material (absorption capacity, fire shrinkage, modulus of elasticity, and compressive strength) were within acceptable limits.

As part of study [69], double-layer cementitious tiles that absorb microwaves were designed based on the theory of impedance matching and the law of electromagnetic wave propagation. Ferrite and carbon fibers were used as an admixture to improve the absorptive properties and band width. A double-layer cementitious microwave absorber was produced and its absorptive properties were evaluated in the frequency range of 8-18 GHz. Compared to the single-layer structure, the reflection coefficient of the doublelayer tiles decreased by about $6-8 \mathrm{~dB}$. The maximum shielding effectiveness of the doublelayer tile containing ferrite and carbon fibers reached $16.2 \mathrm{~dB}$.

Table 5, summarising the materials described in Section 4, is presented below. 
Table 5. Summary of the products described in Section 4.

\begin{tabular}{|c|c|c|c|}
\hline Ref. No. & Year & Product & Description \\
\hline [67] & 2011 & $\begin{array}{l}\text { Ceramic bricks and tiles with } \\
\text { mill scale admixture }\end{array}$ & $\begin{array}{ll}\text { - } & 20 \% \text { MS brickwall, frequency range } 8-12 \mathrm{GHz}, \mathrm{SE}=4-5 \mathrm{~dB} ; \\
\text { - } & 20 \% \mathrm{MS} \text { tilewall, frequency range } 8-12 \mathrm{GHz}, \mathrm{SE}=5-12 \mathrm{~dB}\end{array}$ \\
\hline [68] & 2011 & $\begin{array}{l}\text { Ceramic elements with } \\
\text { metallurgical slag admixture }\end{array}$ & $\begin{array}{l}-\quad 10 \% \text { slag, frequency range } 8-12 \mathrm{GHz}, \mathrm{SE}=2-2.5 \mathrm{~dB} ; \\
-\quad 20 \% \text { slag, frequency range } 8-12 \mathrm{GHz}, \mathrm{SE}=2.5-3 \mathrm{~dB}\end{array}$ \\
\hline [69] & 2009 & $\begin{array}{l}\text { Double-layer cementitious } \\
\text { tiles with ferrite and carbon } \\
\text { fibers admixture }\end{array}$ & $\begin{array}{ll} & \text { frequency range } 8-18 \mathrm{GHz} \\
- & \text { reflectivity }=6-8 \mathrm{~dB} \\
- & \text { maximum reflection loss }-16.2 \mathrm{~dB}\end{array}$ \\
\hline
\end{tabular}

\section{Paint Coatings}

As part of study [70], ferrites containing single- and double-layer paints absorbing microwave radiation were developed. Theoretical and experimental results for the Ku band were compared. The single-layer absorbing paint was found to exhibit a peak absorption of $12.3 \mathrm{~dB}$ at $17.4 \mathrm{GHz}$ for a layer thickness of $1.12 \mathrm{~mm}$. The use of two layers of paint (with a different ferrite content) resulted in band widening, but at the expense of absorption.

Paper [71] presents a method of manufacturing paints and sheets designed to protect against EM radiation along with their specifications. This method was based on polymeric matrices, in which magnetic and dielectric materials were dispersed. In particular, polyurethane was used as a matrix in paints, producing different types containing carbonyl iron or polyaniline. Tests were performed to determine the electric permittivity and magnetic permeability of the materials. Paints and silicone sheets absorbed $60-80 \%$ and $90 \%$ of electromagnetic radiation, respectively. This indicates that these materials can be used for protection against penetration of EM waves through space enclosures.

In patents [72,73], carbon fibers cut such that their length corresponds to half the wavelength to be absorbed are proposed as materials absorbing electromagnetic waves in the high radio and microwave frequency ranges. The fibers are randomly dispersed and embedded in a dielectric binder (Figures 11 and 12, adapted from [72,74]).

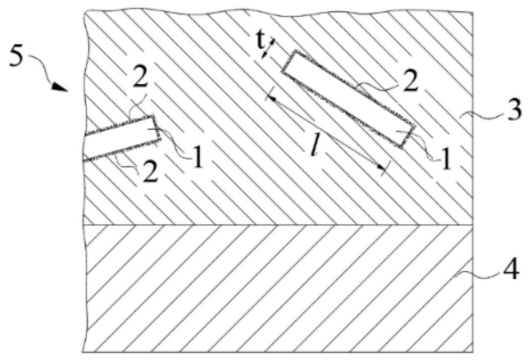

Figure 11. Electromagnetic wave-absorbing material acc. to patent. Designations: 1-fibers, 2-material with low loss factor, e.g., epoxy resin or neat resin, 3-resinous matrix, 4-protected surface, 5-composite coating (after [72]).

According to [72], the fibers can be aluminium, but other materials, such as copper, iron, titanium, and graphite, can also be used. The patent [74] proposes the use of at least two different types of fiber, so that electromagnetic waves can be absorbed in a wider frequency range. The materials described in the patents form an absorbing coating which is easier to apply onto conductive surfaces by spraying, laminating, and painting with a paintbrush. The materials are mainly used in the military sector to protect airplanes, rocket missiles, and other equipment against radar, but they are also used in industry to protect airports and seagoing vessels. 

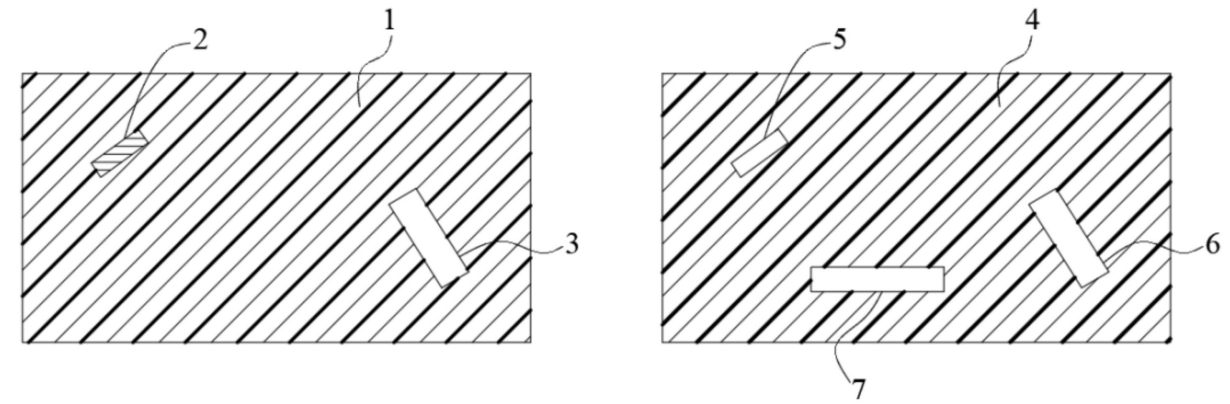

Figure 12. Electromagnetic wave-absorbing material acc. to patent. Designations: 1 and 4-dielectric binding material, such as resin or polymer; 2 and 3 and 5, 6, and 7-fibers with different physical and electrical properties (after [74]).

In patent [73] it is proposed to use aluminosilicates thoroughly mixed with aluminium nitride and then held at a temperature of $800-1000{ }^{\circ} \mathrm{C}$ for an hour. This material can be used as a colourless coating for various structures or machines or to create protective panels shielding structural facades from electromagnetic interference. The material has good mechanical properties and good resistance to a wide range of chemicals, and is easily mouldable.

The materials described in this section are listed in Table 6.

Table 6. Summary of the products described in Section 5 .

\begin{tabular}{|c|c|c|c|}
\hline Ref. No. & Year & Product & Description \\
\hline [70] & 2002 & $\begin{array}{l}\text { Ferrite-containing single- and } \\
\text { double-layer paints }\end{array}$ & $\begin{array}{l}\text { Single-layer paint (thickness of } 1.12 \mathrm{~mm} \text { ): } \\
\text { - } \quad \text { absorption: } 12.3 \mathrm{~dB} \text { at } 17.4 \mathrm{GHz} \text {. } \\
\text { Double-layer paint: } \\
\text { - } \quad \text { band widening, lower absorption. }\end{array}$ \\
\hline [71] & 2010 & $\begin{array}{l}\text { Paints and sheets based on } \\
\text { magnetic and dielectric materials }\end{array}$ & - $\quad$ attenuation: $60-85 \%$ at $8-12.5 \mathrm{GHz}$ \\
\hline$[72,74]$ & 1971, 1997 & $\begin{array}{l}\text { Composite coating: fibers in } \\
\text { dielectric binder }\end{array}$ & $\begin{array}{l}\text { - } \quad \text { the patents present broadband radar absorbing materials; } \\
\text { - } \quad \text { the materials used include aluminium, copper, iron, } \\
\text { titanium, and graphite fibers; } \\
\text { - } \quad \text { application by spraying, laminating, or painting with } \\
\text { a paintbrush }\end{array}$ \\
\hline [74] & 1988 & $\begin{array}{l}\text { Coatings based on } \\
\text { aluminosilicates mixed with } \\
\text { aluminium nitride }\end{array}$ & $\begin{array}{l}\text { - } \quad \text { material for coatings or protective panels for structures } \\
\text { and machines; } \\
\text { - } \quad \text { the material protects from electromagnetic interference; } \\
\text { electromagnetic field shielding composite in the } \mathrm{GHz} \\
\text { frequency range }\end{array}$ \\
\hline
\end{tabular}

\section{Final Conclusions}

\subsection{Summary of Review}

This review of the literature focused on the possible uses of HPM radiation absorbers in building products and structures. The attention was concentrated on four principle types of elements: claddings, concrete and mortar, small-sized elements (bricks and hollow masonry units), and paint coatings. On the basis of literature on the subject, examples of $\mathrm{HPM}$ radiation absorbers having high potential to be combined with basic construction materials were given in each of the categories. In the case of structural elements (concrete, mortar, bricks, and hollow masonry units), the main criterion for selecting absorbing additions, besides their shielding effectiveness, was no (or minimal) adverse effect on the basic mechanical and non-mechanical properties of the building materials.

This survey shows that the simplest and at the same time most effective way of protecting buildings or their rooms against the harmful action of HPM is shielding with 
claddings. The shielding effect can be achieved using metal shields [32] in the form of plates or nets [34], but to improve their effectiveness, it is worth considering multilayer shields that contain combinations of various metals or alloys (e.g., copper, Mumetal, iron, aluminium, steel) [33]. In addition, the use of composite boards, such as carbon-containing honeycomb gypsum plasterboards [35], mineral wool boards with carbon black addition [36], sandwich boards [38], or carbon fiber paper as used successfully in plywood production [37], can be an effective solution.

Regarding concretes and mortars, the literature review indicates that various admixtures and additions, which must be properly dispersed in the volume of concrete or mortar, are used to obtain the desired level of shielding effectiveness. Steel, graphite, metallurgical slag, nickel, copper, carbon nanotubes, ferrites, and carbon black are the additions most frequently mentioned in the literature. To achieve maximally high effectiveness against EM radiation, it is recommended that the size of individual particles be equal to $1 \mu \mathrm{m}$ or less, but in the case of such small particles, their proper dispersion in concrete is difficult [44]. Larger fibers or particles are also used, but in this case the drawback is that the interior of each fiber or particle does not contribute to radiation protection, therefore requiring the use of higher fiber or particle contents (volumes) $[45,46]$. An addition of carbon or steel fiber not only improves the absorption of electromagnetic waves [47], but can also improve mechanical characteristics (compressive strength, flexural strength, and fatigue strength) [48], physical characteristics (thermal conductivity and electrical conductivity) and deformability (shrinkage) [49]. Furthermore, a change in the proportions of the cementitious composite components results in a change in the frequency ranges in which waves are absorbed [50]. A carbon black addition to concrete or mortar improves electric permittivity, as a result of which the thickness and weight of the absorber can be reduced.

Another group of building materials are small-sized elements in the form of bricks and hollow masonry units. The authors of the articles dealing with such elements with respect to protection against EM radiation proposed the use of, i.a., a mill scale admixture in the manufacture of ceramic bricks with enhanced shielding effectiveness [67], a metallurgical slag addition to ceramic elements [68] and a ferrite and carbon fiber addition to double-layer cementitious tiles [69].

The last considered group of materials that ensure protection against HPM pulses comprises paint coatings. This review covered the following materials belonging to this group: microwave radiation-absorbing single- and double-layer paints based on ferrite [70], paints and sheets based on magnetic and dielectric materials dispersed in polymeric matrices [71], dielectric binders with an addition of carbon fibers cut such that their length corresponds to half the wavelength to be absorbed [72,74], and colourless coatings produced from aluminosilicates mixed with aluminium nitride [73].

\subsection{Implications for Practice}

Based on this review of the literature and the experience of the authors gained from a vast research project aimed at developing a technology to manufacture anti-HPM building absorbers, the following general conclusion can be drawn: the development of a building material (concrete, mortar) or element (a brick, a masonry unit, a wall) is a complex problem and requires an interdisciplinary approach. Collaboration between scientists from the fields of, i.a., chemistry, electronics, and building engineering is essential. Each of the teams should supervise the respective component of the project. The task of chemistry specialists would be to select proper HPM-absorbing materials as additions to building materials. The task of electronics engineers would be to test the prototypes of manufactured building materials with regard to HPM protection. The team of building engineers would be responsible for the manufacture of prototypes, ensuring their desired mechanical and non-mechanical properties. When undertaking the interdisciplinary research project (as mentioned in the Funding section) the authors formulated the following procedure for developing construction materials for the protection of buildings against HPM pulses: (1) carry out preliminary studies to obtain information about promising absorbers which 
could be added as fillers to cement-based materials, (2) prepare composites and carry out tests on building absorber prototypes, (3) develop a hybrid solution (e.g., for a multilayer wall) by combining several different protection methods, (4) obtain approvals, certificates, etc., and (5) implement industrial scale production.

As stated in the Introduction, the solutions being developed need to meet the three criteria concerning requirements for building products, suitable shielding effectiveness, and reasonable costs. These criteria set basic limitations on any products designed to protect against HPM pulses. Therefore, development of such products should always be a result of multi-criteria analyses and/or optimization. Furthermore, one should bear in mind that the development of building materials providing a barrier against HPM pulses is not enough to ensure the full protection of buildings. The walls of buildings have door openings and often window openings, which are the weak points in the shielding. Furthermore, the wiring systems (e.g., mains power supply, lighting, data transmission systems) and plumbing systems (e.g., air conditioning, ventilation, water and drainage piping) pose a problem. In order to achieve the desired shielding effectiveness for the whole building and so eliminate discontinuities in the EM barrier, various kinds of EM shields are usually used. Regarding windows and doors, protection can be achieved using metal nets with a suitably matched mesh size, or metallised glass panes. Moreover, it is essential to use special electromagnetic seals (e.g., copper-beryllium finger door seals). Ventilation openings can be protected using EM barriers in the form of damping waveguides or metal nets with variously shaped meshes (e.g., orthogonal, honeycomb) [33].

The patent solutions and scientific papers cited in this review give grounds for formulating the following basic conclusion concerning a hybrid anti-HPM building absorber: the development of a space-dividing element in the form of a multilayer wall, providing effective protection of a building against EM pulses in a wider frequency range, is a complex but achievable task. The task can be achieved through combining the attributes of the particular materials that comprise the layers of a hybrid building absorber. Ensuring the continuity of the EM barrier by matching proper absorber layers and protecting all openings in the wall, one can achieve comprehensive protection of buildings against HPM. The development of a solution in the form of a hybrid multilayer wall is the subject of the R\&D investigations currently conducted by the authors. The results of these investigations will be presented in future articles.

Author Contributions: Conceptualization: A.R. and T.T.; Investigation: K.M., M.M., W.P., A.R., M.S. and T.T.; Project Administration: T.T.; Resources: K.M., M.M., W.P., A.R., M.S. and T.T.; Supervision: T.T. and M.M.; Visualization: M.M., K.M., W.P. and M.S.; Writing-Original Draft: K.M. and W.P.; Writing-Review \& Editing: M.M., A.R. and M.S. All authors have read and agreed to the published version of the manuscript.

Funding: Badania zostały sfinansowane przez NCBiR-Umowa DOB-1-3/1/PS/2014 pn. “Metody i sposoby ochrony i obrony przed impulsami HPM" w ramach programu strategicznego "Nowe systemy uzbrojenia i obrony w zakresie energii skierowanej". The work was supported by the Polish National Centre for Research and Development within the project "Methods and ways of protection and defence against HPM impulses", pending within the strategic project: "New weaponry and defense systems of directed energy".

Institutional Review Board Statement: Not applicable.

Informed Consent Statement: Not applicable.

Conflicts of Interest: The authors declare no conflict of interest.

\section{References}

1. Dras, M.; Kałuski, M.; Szafrańska, M. HPM pulses—Disturbances and systems interaction—Basic issues. Przeglad Elektrotechniczny 2015, 1, 13-16. (In Polish) [CrossRef]

2. Schamiloglu, E. High power microwave sources and applications. In Proceedings of the International Microwave Symposium Digest, Fort Worth, TX, USA, 6-11 June 2004. 
3. Lu, Z.; Jian, C.; Wan, S.; Liu, P. Research on new technology on protection of electronic systems from high power electromagnetic pulse. In Proceedings of the Progress in Electromagnetics Research Symposium Proceedings, Xi'an, China, $22-26$ March 2010.

4. Schurig, D.; Mock, J.J.; Justice, B.J.; Cummer, S.A.; Pendry, J.B.; Starr, A.F.; Smith, D.R. Metamaterial electromagnetic cloak at microwave frequencies. Science 2006, 314, 977-980. [CrossRef]

5. Lois, G. Electromagnetic Absorption of a Nickel Zinc Ferrite System at Low Frequency; The Ohio State University: Columbus, OH, USA, 1999.

6. Liu, Y.; Luo, F.; Su, J.; Zhou, W.; Zhu, D. Electromagnetic and microwave absorption properties of the $\mathrm{Nickel} / \mathrm{Ti}_{3} \mathrm{SiC}_{2} \mathrm{hybrid}$ powders in X-band. J. Magn. Magn. Mater. 2014, 365, 126-131. [CrossRef]

7. Yu, Y.; Ma, H.; Tian, X.; Du, H.; Xia, S.; Qu, S. Synthesis and electromagnetic absorption properties of micro-nano nickel powders prepared with liquid phase reduction method. J. Adv. Dielectr. 2016, 6, 1650025. [CrossRef]

8. Ma, Z.; Wang, J.; Liu, Q.; Yuan, J. Microwave absorption of electroless Ni-Co-P-coated $\mathrm{SiO}_{2}$ powder. Appl. Surf. Sci. 2009, 255, 6629-6633. [CrossRef]

9. Fang, J.; Zha, W.; Kang, M.; Lu, S.; Cui, L.; Li, S. Microwave absorption response of nickel/graphene nanocomposites prepared by electrodeposition. J. Mater. Sci. 2013, 48, 8060-8067. [CrossRef]

10. Zhang, H.; Tian, X.; Wang, C.; Luo, H.; Hu, J.; Shen, Y.; Xie, A. Facile synthesis of RGO/NiO composites and their excellent electromagnetic wave absorption properties. Appl. Surf. Sci. 2014, 314, 228-232. [CrossRef]

11. Słonka, T.; Głowiński, J.; Baczyńska, T.; Hałat, A. Material Absorbing Electromagnetic Waves. PL Patent 203,956 B1, Filed 20 October 2003, Patented 30 November 2009. (In Polish)

12. Regulation (EU) No 305/2011 of the European Parliament and of the European Council of 9 March 2011 laying down harmonised conditions for the marketing of construction products and repealing Council Directive 89/106/EEC. Available online: https: / / eur-lex.europa.eu/legal-content/EN/TXT/?uri=celex\%3A32011R0305 (accessed on 1 July 2021).

13. Act of 7 July 1994 construction law. Journal of Laws of the Republic of Poland, No. 89, item 414. Available online: https: / / www.global-regulation.com/translation/poland/2986349/the-act-of-7-july-1994\%252c-construction-law.html (accessed on 1 July 2021).

14. Act of 16 April 2004 on construction products. Journal of Laws of the Republic of Poland, No. 92, item 881. Available online: https:/ / www.global-regulation.com/translation/poland/3353949/the-act-of-16-april-2004-on-the-protection-of-nature. html (accessed on 1 July 2021).

15. Majcher, K.; Musiał, M.; Pakos, W.; Różański, A.; Sobótka, M.; Trapko, T. Methods of protecting buildings against HPM radiation-A review of materials absorbing the energy of electromagnetic waves. Materials 2020, 13, 5509. [CrossRef]

16. Guan, H.; Liu, S.; Duan, Y.; Cheng, J. Cement based electromagnetic shielding and absorbing building materials. Cem. Concr. Compos. 2006, 28, 468-474. [CrossRef]

17. Cao, J.; Chung, D.D.L. Colloidal graphite as an admixture in cement and as a coating on cement for electromagnetic interference shielding. Cem. Concr. Res. 2003, 33, 1737-1740. [CrossRef]

18. Cao, J.; Chung, D.D.L. Coke powder as an admixture in cement for electromagnetic interference shielding. Carbon 2003, 41, 2433-2436. [CrossRef]

19. Chen, P.W.; Chung, D.D.L. A comparative study of concretes reinforced with carbon, polyethylene, and steel fibers and their improvement by latex addition. ACI Mater. J. 1996, 93, 129-133. [CrossRef]

20. Giergiczny, Z. Fly Ash in Cement and Concrete Composition, 2nd ed.; Publishing House of Silesian University of Technology: Gliwice, Poland, 2013. (In Polish)

21. Wu, L.Z.; Ding, J.; Jiang, H.B.; Chen, L.F.; Ong, C.K. Particle size influence to the microwave properties of iron based magnetic particulate composites. J. Magn. Magn. Mater. 2005, 285, 233-239. [CrossRef]

22. Meng, W.; Yuping, D.; Shunhua, L.; Xiaogang, L.; Zhijiang, J. Absorption properties of carbonyl-iron/carbon black double-layer microwave absorbers. J. Magn. Magn. Mater. 2009, 321, 3442-3446. [CrossRef]

23. Pretorius, J.C.; Maharaj, B.T. Improvement of electromagnetic wave (EMW) shielding through inclusion of electrolytic manganese dioxide in cement and tile-based composites with application for indoor wireless communication systems. Int. J. Phys. Sci. 2013, 8, 295-301. [CrossRef]

24. Zhang, X.; Sun, W. Microwave absorbing properties of double-layer cementitious composites containing Mn-Zn ferrite. Cem. Concr. Compos. 2010, 32, 726-730. [CrossRef]

25. Guan, B.; Ding, D.; Wang, L.F.; Wu, J.; Xiong, R. The electromagnetic wave absorbing properties of cement-based composites using natural magnetite powders as absorbers. Mater. Res. Express 2017, 4, 051603. [CrossRef]

26. Wang, D.; Yang, P.; Hou, P.; Zhang, L.; Zhang, X.; Zhou, Z.; Xie, N.; Huang, S.; Cheng, X. Cement-based composites endowed with novel functions through controlling interface microstructure from $\mathrm{Fe}_{3} \mathrm{O}_{4} @ \mathrm{SiO}_{2}$ nanoparticles. Cem. Concr. Compos. 2017, 80, 268-276. [CrossRef]

27. Gaitero, J.; Campillo, I.; Guerrero, A. Reduction of the calcium leaching rate of cement paste by addition of silica nanoparticles. Cem. Concr. Res. 2008, 38, 1112-1118. [CrossRef]

28. Esfahani, A.S.; Katbab, A.A.; Dehkhoda, P.; Karami, H.R.; Barikani, M.; Sadeghi, S.H.H.; Ghorbani, A. Preparation and characterization of foamed polyurethane/silicone rubber/graphite nanocomposite as radio frequency wave absorbing material: The role of interfacial compatibilization. Compos. Sci. Technol. 2012, 72, 382-389. [CrossRef] 
29. Méjean, C.; Pometcu, L.; Benzerga, R.; Sharaiha, A.; Le Paven-Thivet, C.; Badard, M.; Pouliguen, P. Electromagnetic absorber composite made of carbon fibers loaded epoxy foam for anechoic chamber application. Mater. Sci. Eng. B 2017, $220,59-65$. [CrossRef]

30. Xingjun, L.; Mingli, C.; Yan, L.; Xin, L.; Qian, L.; Rong, T.; Qi, W.; Yuping, D. A new absorbing foam concrete: Preparation and microwave absorbing properties. Adv. Concr. Constr. 2015, 3, 103-111. [CrossRef]

31. Mehdiabadi, A.; Tabatabeinasab, M.; Spulbar, C.; Yazdi, A.K.; Birau, R. Are we ready for the challenge of Banks 4.0? Designing a roadmap for banking systems in Industry 4.0. Int. J. Financ. Stud. 2020, 8, 32. [CrossRef]

32. Kumar, K.K.S.; Rao, C.R.K.; Vijayan, M.; Trivedi, D.C. EMI shielding: Methods and materials-A review. J. Appl. Polym. Sci. 2009, 112, 2073-2086. [CrossRef]

33. Chmielińska, J.; Kuchta, M.; Kubacki, R.; Dras, M.; Wierny, K. Selected methods of protection of electronic devices against electromagnetic weapons. Przeglą Elektrotechniczny 2016, 92, 1-8. (In Polish) [CrossRef]

34. Kessel, W. Electromagnetic Shielding. U.S. Patent 7,576,289 B2, Filed 17 May 2006, Patented 18 August 2009.

35. Xie, S.; Ji, Z.; Yang, Y.; Hou, G.; Wang, J. Electromagnetic wave absorption properties of honeycomb structured plasterboards in S and $C$ bands. J. Build. Eng. 2016, 217, 217-223. [CrossRef]

36. Xie, S.; Yang, Y.; Hou, G.; Wang, J.; Ji, Z. Development of layer structured wave absorbing mineral wool boards for indoor electromagnetic radiation protection. J. Build. Eng. 2016, 5, 79-85. [CrossRef]

37. Yuan, Q.P.; Lu, K.Y.; Fu, F. Process and structure of electromagnetic shielding plywood composite laminated with carbon fiber paper. Open Mater. Sci. J. 2014, 8, 99-107. [CrossRef]

38. Hirose, K. Electromagnetic Wave Absorber. U.S. Patent 2014/0132439 A1, Filed 9 July 2013, Patented 15 May 2014.

39. Joshi, V.; Kimura, K.; De Araujo, C.A.P.; Kiyokawa, H. Materials for Electromagnetic Wave Absorption Panels. U.S. Patent 5,853,889, Filed 13 January 1997, Patented 29 December 1998.

40. Timmerman, A.T. Microwave-Absorbing Material. EP Patent 0420513 A1, Filed 21 September 1990, Patented 3 April 1995.

41. Mayer, P.; Kaczmar, J.; Sowa, A.; Vogt, A.; Kołodziej, H.; Strzelecki, S. Energy-Absorbing Coating, Especially the Energy Electromagnetic and Mechanical Waves. Patent 405,814, Filed 28 October 2013, Patented 4 August 2014. (In Polish)

42. Tian, X.; Hu, H. Test and study on electrical property of conductive concrete. Procedia Earth Planet. Sci. 2012, 5, 83-87. [CrossRef]

43. Los, P.; Lukomska, A.; Jeziorska, R. Metal-polymer composites for electromagnetic interference shielding applications. Polimery 2016, 61, 663-669. [CrossRef]

44. Chung, D.D.L. Dispersion of short fibers in cement. J. Mater. Civ. Eng. 2005, 17, 379-383. [CrossRef]

45. Chung, D.D.L. Comparison of submicron-diameter carbon filaments and conventional carbon fibers as fillers in composite materials. Carbon 2001, 39, 1119-1125. [CrossRef]

46. Chung, D.D.L. Materials for electromagnetic interference shielding. J. Mater. Eng. Perform. 2000, 9, 350-354. [CrossRef]

47. Chiou, J.M.; Zheng, Q.; Chung, D.D.L. Electromagnetic interference shielding by carbon fiber reinforced cement. Composites 1989, 20, 379-381. [CrossRef]

48. Kim, T.-J.; Park, C.K. Flexural and tensile strength developments of various shape carbon fiber-reinforced lightweight cementitious composites. Cem. Concr. Res. 1998, 28, 955-960. [CrossRef]

49. Chung, D.D.L. Cement reinforced with short carbon fibers: A multifunctional material. Compos. Part B 2000, 31, 511-526. [CrossRef]

50. Zhang, X.; Sun, W. Electromagnetic shielding and absorption properties of fiber reinforced cementitious composites. J. Wuhan Univ. Technol. Mater. Sci. Ed. 2012, 27, 172-176. [CrossRef]

51. Laukaitis, A.; Sinica, M.; Balevičius, S.; Levitas, B. Investigation of electromagnetic wave absorber based on carbon fiber reinforced aerated concrete using time-domain method. Acta Phys. Pol. A 2008, 113, 1047-1050. [CrossRef]

52. Zhang, Y.F.; Li, B.Y.; Liu, S.H.; Hao, W.J. Electromagnetic wave absorption properties and mechanical properties of aramid fiber reinforced cement. Adv. Mater. Res. 2012, 512, 2873-2877. [CrossRef]

53. Wei, Y.; Zhang, Y.; Hao, W. Electromagnetic wave absorption properties of glass fiber reinforced cement filled with carbon black. Adv. Mater. Res. 2014, 912-914, 127-130. [CrossRef]

54. Yee, S.K.; Jenu, M.Z.M. Shielding effectiveness of concrete with graphite fine powder in between $50 \mathrm{MHz}$ to $400 \mathrm{MHz}$. In Proceedings of the 2013 Asia-Pacific Symposium on Electromagnetic Compatibility (APEMC), Melbourne, Australia, 20-23 May 2013. [CrossRef]

55. Khushnood, R.A.; Ahmed, S.; Savi, P. Improvement in electromagnetic interference shielding effectiveness of cement composites using carbonaceous nano/micro inerts. Constr. Build. Mater. 2015, 85, 208-216. [CrossRef]

56. Frenzel, T.; Stumpf, J.; Koch, M. Shielding effectiveness of original and modified building materials. Adv. Radio Sci. 2007, 5, 69-73. [CrossRef]

57. Wen, S.; Chung, D.D.L. Electromagnetic interference shielding reaching $70 \mathrm{~dB}$ in steel fiber cement. Cem. Concr. Res. 2004, 34 , 329-332. [CrossRef]

58. De Leo, R.; Gradoni, G.; Mazzoli, A.; Moglie, F.; Moriconi, G.; Primiani, W.M. DSP cement composites for electromagnetic shielding: Practice and experimental analysis. In Proceedings of the 2009 International Symposium on Electromagnetic CompatibilityEMC Europe, International Symposium on Electromagnetic Compatibility, Athens, Greece, 11-12 June 2009. [CrossRef]

59. Nam, I.W.; Lee, H.K.; Sim, J.B.; Choi, S.M. Electromagnetic characteristics of cement matrix materials with carbon nanotubes. ACI Mater. J. 2012, 109, 363-370. [CrossRef] 
60. Yafei, S.; Peiwei, G.; Hailong, P.; Honwei, L.; Xiaolin, L.; Kai, S. Electromagnetic wave absorbing and mechanical properties of cement-based composite panel with different nanomaterials. Adv. Compos. Lett. 2017, 26, 6-11. [CrossRef]

61. Zhang, X.; Sun, W. Three-layer microwave absorber using cement-based composites. Mag. Concr. Res. 2011, 63, 157-162. [CrossRef]

62. Wu, F.; Hao, W.; Zhang, Y.; Wang, M.; Chen, D.; Yi, Y.; Zhao, H.; Dong, Y.; Yu, X. The double-layer matching design of broad-band foam cement absorbing panel for electromagnetic pollution control. Appl. Mech. Mater. 2013, 401-403, 924-928. [CrossRef]

63. Guan, H.; Liu, S.; Duan, Y. Expanded polystyrene as an admixture in cement-based composites for electromagnetic absorbing. J. Mater. Eng. Perform. 2007, 16, 68-72. [CrossRef]

64. Hongtao, G.; Shunhua, L.; Yuping, D.; Yanbo, Z. Investigation of the electromagnetic characteristics of cement based composites filled with EPS. Cement Concr. Comp. 2007, 29, 49-54. [CrossRef]

65. Chung, D.D.L.; Zheng, Q.J. Electronic properties of carbon fiber reinforced gypsum plaster. Compos. Sci. Technol. 1989, 36, 1-6. [CrossRef]

66. Kołodziej, H.; Vogt, A.; Sowa, A.E.; Cichy, A.; Strzelecki, S. Electromagnetic Energy Absorbing Material. UK Patent GB 2379331A, Filed 28 March 2001, Patented 5 March 2003.

67. Bantsis, G.; Sikalidis, C.; Betsiou, M.; Yioultsis, T.; Xenos, T. Electromagnetic absorption, reflection and interference shielding in X-band frequency range of low cost ceramic building bricks and sandwich type ceramic tiles using mill scale waste as an admixture. Ceram. Int. 2011, 37, 3535-3545. [CrossRef]

68. Bantsis, G.; Sikalidis, C.; Betsiou, M.; Yioultsis, T.; Bourliva, A. Ceramic building materials for electromagnetic interference shielding using metallurgical slags. Adv. Appl. Ceram. 2011, 110, 233-237. [CrossRef]

69. Zhang, X.Z.; Sun, W. Investigation on microwave absorbing properties of double-layer cementitious composites. Adv. Mat. Res. 2009, 79-82, 1843-1846. [CrossRef]

70. Meshram, M.R.; Agrawal, N.K.; Sinha, B.; Misra, P.S. A study on the behaviour of M-type barium hexagonal ferrite based microwave absorbing paints. B. Mater. Sci. 2002, 25, 169-173. [CrossRef]

71. Folgueras, L.; Alves, M.; Rezende, M.C. Microwave absorbing paints and sheets based on carbonyl iron and polyaniline: Measurement and simulation of their properties. J. Aerosp. Technol. Manag. 2010, 2, 63-70. [CrossRef]

72. Stander, M. Radar Absorptive Coating. U.S. Patent 3,599,210, Filed 18 November 1969, Patented 10 August 1971.

73. Chassay, G.; Citerne, J.; Floc'h, J.M.; Guyader, J.; Laurent, Y.; L’Haridon, P.; Rolland, A.; Verdier, P. Electromagnetic Radiation Absorbing Material, in Particular Microwaves, its Manufacturing Process and its Application as a Coating Material. French Patent 2695 760, Filed 17 February 1988, Patented 18 March 1994. (In French)

74. Shumaker, G.P.; May, B.W. Multi-Fiber Species Artificial Dielectric Radar Absorbing Material and Method for Producing Same. U.S. Patent 5,661,484, Filed 5 July 1996, Patented 26 August 1997. 